NBER WORKING PAPER SERIES

\title{
POPULATION AGING, SAVINGS BEHAVIOR AND CAPITAL MARKETS
}

\author{
Axel H. Boersch-Supan \\ Joachim K. Winter \\ Working Paper 8561 \\ http://www.nber.org/papers/w8561 \\ NATIONAL BUREAU OF ECONOMIC RESEARCH \\ 1050 Massachusetts Avenue \\ Cambridge, MA 02138 \\ October 2001
}

\begin{abstract}
We would like to thank Giuseppe Bertola, Silke Januszewski, Jens Köke, Jan Walliser, and Alfons Weichenrieder for helpful comments. Melanie Lührmann, Florian Heiss, and Alexander Ludwig provided dedicated assistance and thoughtful feedback. Financial Support by the Deutsche Forschungsgemeinschaft through Sonderforschungsbereich 504 is gratefully acknowledged. The views expressed herein are those of the authors and not necessarily those of the National Bureau of Economic Research.
\end{abstract}

(C) 2001 by Axel H. Boersch-Supan and Joachim K. Winter. All rights reserved. Short sections of text, not to exceed two paragraphs, may be quoted without explicit permission provided that full credit, including (C) notice, is given to the source. 
Population Aging, Savings Behavior and Capital Markets

Axel H. Boersch-Supan and Joachim K. Winter

NBER Working Paper No. 8561

October 2001

\begin{abstract}
$\underline{\text { ABSTRACT }}$
Population aging is just beginning to hit the industrialized countries in full force, and it will have a tremendous impact on capital markets. In this paper, we argue that the capital market effects of population aging are particularly strong in continental European economies such as Germany, France, and Italy, with their large and ailing pay-as-you-go public pension systems, relatively thin capital markets, and poor capital performance. The younger generations in these countries are quite aware of the need to provide for more retirement income through own private saving, and these effects will be accentuated by fundamental pension reforms that aim at more pre-funding. Population aging changes households' savings behavior and portfolio composition, and much more assets will be invested on the stock market. Capital markets will grow in size, and active institutional investors such as pension funds will become more important in continental European countries. These changes are likely to have beneficial side effects in terms of improved capital efficiency, total factor productivity, and growth. Looking at the effects of population aging on savings behavior and capital markets therefore adds a new dimension to the continuing debate about advantages and disadvantages of pay-as-you-go and fully funded pension systems.
\end{abstract}

Axel H. Boersch-Supan

Mannheim Research Institute for the Economics of Aging (MEA)

Department of Economics

University of Mannheim

D-68131 Mannheim, Germany

and NBER

Fax: +49-621-181-1863

Email: Axel@Boersch-Supan.de

Joachim K. Winter

Sonderforschungsbereich 504

University of Mannheim

D-68131 Mannheim, Germany

and Department of Economics, University of California, Berkeley

Email: winter@uni-mannheim.de 


\section{Contents}

\section{Introduction}

2. Why and how demographic change affects capital markets

2.1 Demographic change and pay-as-you-go pension systems

2.2 Quantitative predictions of the capital markets effects of aging and pension reform

3. A closer look at life-cycle saving and portfolio decisions

3.1 Life-cycle saving patterns

3.2 Portfolio composition

4. How strong capital markets enhance productivity and growth

4.1 Financial market conditions and growth

4.2 Potential reasons for long-term performance differences

4.3 Active pension funds, corporate governance and firm performance

\section{Conclusions}

\section{References}

\section{Tables}

Figures 


\section{Introduction}

France, Germany and Italy, to take the three largest economies in continental Europe, have large pay-as-you-go public pension systems that face severe problems due to population aging (see OECD, 1988, and World Bank, 1994). As computed by the International Monetary Fund (Chand and Jaeger, 1996), the size of the public pension systems as a percentage of GDP will increase by about 50 percent from 1995 to 2030 in France and in Italy, and almost double in Germany, if benefits stay as they were in 1992 in real terms (see table 1-1). If the additional expenditures are financed solely by contributions, these will rise approximately in proportion. Expressed as a percentage of the wage bill, French workers would then pay 38 percent to their pension system in the year 2030 rather than 24 percent in 1995. In Germany, the contribution rate would rise to 41 percent, and in Italy even to 62 percent of the wage bill. If the additional burden was financed solely by debt, it would exceed 100 percent of GDP in France, 115 percent in Germany, and as much as 180 percent in Italy by the year 2035. Similar numbers have been published by the OECD (Rosevaere et al., 1996).

At the same time, France, Germany and Italy have thin capital markets in the sense that only few households own and control productive capital (either directly or via investment and pension funds). French, German and Italian savers hold a considerable smaller share of stocks than AngloSaxon households. As a result, stock market capitalization is low in these three countries, and pension funds play only a minor role in household saving (see table 1-2).

Finally, France, Germany and Italy have, in comparison to the United States, poor capital performance as measured by capital productivity and various rates of return. While international comparisons of these statistics are difficult and controversial, the existing evidence yields a clear picture, as summarized in table 1-3. Firms in France and Germany have substantially lower capital productivity and return on investment than U.S. companies achieve. Relative to the United States, financial underperformance is also correlated with lower levels total factor productivity. Many authors claim that an important cause for this underperformance is weak corporate governance (see, e.g., Wenger and Kaserer, 1998; Börsch-Supan, 1998b; Mueller and Yurtoglu, 2000).

The linkages among these three observations are a fascinating subject for economic policy. This is the topic of this paper. It explores the triangle of (i) population aging and pension reform, (ii) 
life-cycle saving and portfolio decisions, and (iii) capital markets, productivity, and economic growth, depicted in figure 1-1. We argue that population aging and pension reform, via a change in the savings behavior and portfolio composition of households, and via strengthening capital allocation and corporate governance through active institutional investors such as pension funds, can have important beneficial side effects on productivity and growth.

Our line of argument is as follows. Population aging (or, more generally, demographic change) is a fact in virtually all countries, with substantial differences in timing. Population aging will change households' saving behavior - even if current pension systems were to be maintained because their internal rate of return will decrease, making own savings as a vehicle for retirement income both more necessary and attractive. Moreover, in many countries, such as France, Italy, and Germany, population aging makes fundamental reform of public pension systems a top priority, strengthening own savings for retirement. We show that this results in rising aggregate savings and capital stocks over the first decades of this century, while thereafter, when the demographic change is over, the higher old-age dependency ratio will lead to lower savings rates. Our quantitative predictions show that the amount of additional capital generated until about 2035 is substantial. Finally, increased household saving and changes in households' portfolio structure will also change the nature of capital markets, in particular in those countries that implement fundamental pension reforms. Even if no additional savings were created, a higher share of savings will flow through traded shares and bonds. There is ample evidence that the size of capital markets and productivity growth are related. There is also reason to believe that larger capital markets and actively managed investment and pension funds enhance corporate governance.

More concretely, few households in continental European countries such as France, Germany and Italy hold financial assets with at least some minimal ownership rights. Those assets are highly concentrated among only few households, in stark contrast to countries in which a substantial share of retirement income is financed through pension funds. ${ }^{1}$ A lack of relatively actively managed pension funds results in diffuse (e.g., pyramidal) corporate control structures and weak corporate governance, and thus lowers capital productivity relative to other countries. Pension re-

1 We use the word pension fund in the literal sense and strictly distinguish it from unfunded (pay-as-you-go financed) pension systems - for example, the U.S. Social Security trust fund is not a pension fund in this sense. 
form towards a higher degree of pre-funding can therefore broaden and deepen capital markets, improve capital allocation, strengthen corporate governance, increase capital productivity at constant or even increasing levels of labor productivity, and therefore increase total factor productivity.

Research on these complex issues has not yet come far. Evidence on firm performance in fundamentally different institutional settings is scarce, and establishing causality to explain observed differences is particularly difficult. The aim of this paper are to provide a coherent framework for this line of research, to use a formal model to quantify potential effects, to gather the empirical evidence that is already available, and to highlight potential implications for public policy. To this end, we focus on France, Germany and Italy because these three largest countries in continental Europe have a particularly severe aging problem and at the same time very monolithic public payas-you-go systems in need of reform. Examples from Germany appear a bit more frequent - besides knowing this country better than others, we think that Germany is of particular interest also to an international audience: Germany is a leading example for an institutional setting with both a paternalistic, overly generous but unsustainable public pension system, and a bank-based corporate governance system with concentrated ownership and poor shareholder protection.

The remainder of the paper is structured like the triangle in figure 1-1. In Section 2, we discuss how population aging and pension reform affect capital markets from a macroeconomic perspective, and we compute the size of the capital stock generated by households' optimal response to population aging and a realistic transition to a partially funded system, using Germany as an example. The potential magnitude of capital stock changes is an important factor since it shows that pension reform has a large leverage for changes in capital market structure and macroeconomic performance. Section 3 delivers a picture of households' life-cycle saving decisions in France, Germany and Italy, in particular portfolio choice, and links it to the pension systems in those countries. We then discuss how saving patterns are going to change as a reaction to the decreasing generosity of public pension systems. In Section 4, we discuss the role of capital markets for productivity and economic growth. We consider the overall size and liquidity of capital markets, and more specifically, the potential role of activist pension and investment funds in corporate governance. Section 5 summarizes and concludes. 


\section{Why and how demographic change affects capital markets}

This section has two purposes. First, we show that Europe's public pay-as-you-go pension systems face severe problems which can hardly be solved without a introducing a substantial degree of pre-funding. Hence, capital markets and their governance mechanisms will play an increasingly important role in the future. Second, we show how large this role is likely to be under realistic assumptions. Specifically, we use an macroeconomic simulation model to predict the capital market effects of population aging, and of introducing a funded component to pension systems.

\subsection{Demographic change and pay-as-you-go pension systems}

As is well known, population aging is particularly severe in continental Europe, particularly in Italy and Germany. According to EcoFin (2000), Germany's old-age dependency ratio (i.e., the ratio of the number of persons aged 65 and older and the number of persons between ages 20 and 64) will more than double from $26.0 \%$ in 2000 to $54.7 \%$ in 2040 . Even worse in Italy where the old-age dependency ratio will increase from $28.8 \%$ to $63.9 \%$ during this period. By this measure, Italy will have the oldest population in Europe. France will experience a milder aging process with dependency ratios that are below the European OECD average, but still substantially above those in the United Kingdom and the United States.

Most European countries have contribution-based pay-as-you-go pension systems (which are also the dominant financing mechanisms of old-age social security around the globe), with the Netherlands, Switzerland, and the United Kingdom being notable exceptions. Typical examples for the continental European pension system are France, Germany and Italy whose public pension systems are monolithical, cover almost all workers and provide most of their retirement incomes through a single system. ${ }^{2}$ Until recently, the French, German and Italian pension systems have been very successful in providing a high and reliable level of retirement income. However, times have changed. All three countries have experienced a flurry of pension reforms in recent years,

2 For a detailed description of the pension systems in France see Blanchet (1999), in Germany see Börsch-Supan and Schnabel (1999), and in Italy see Brugiavini (1999). A critical evaluation of the micro- and macroeconomic features of the German public pension system can be found in Börsch-Supan (2000). 
but they have not succeeded in stabilizing contribution rates, public support, and system enrollment. There are two main reasons for the increasing difficulties of these public pension systems: population aging and negative incentive effects on labor supply. In particular, demographic problems have been exacerbated by a strong decrease in labor force participation due to early retirement and unemployment, and by a shift to jobs that escape social security taxation. The declining labor force participation in these countries can at least partially be attributed to the negative incentive effects of their public pension systems (Gruber and Wise, 1999; Schnabel, 1999a).

Because of continuing population aging, contribution rates to public pensions must increase dramatically from their already high levels in the first half of this century if current replacement rates were to be maintained. Population aging is therefore a serious threat to the stability of the European pay-as-you-go public pension systems. The share of social security contributions in total labor compensation already exceeds 50 percent in France, Germany and Italy. Because they are largely viewed as taxes rather than insurance premia (Boeri, Börsch-Supan, and Tabellini, 2001), they increase the wedge between workers' net income and total labor costs to the employers, reducing labor supply and creating an obstacle to competitiveness vis-à-vis countries in Eastern Europe, the United Kingdom and the United States that have lower total labor compensation (see, e.g., OECD, 2000). Hence, increasing those contribution rates to the extent described appears unrealistic, particularly so because health costs will also rise, and probably even faster than public pension costs (OECD, 1988). We do not review the arguments that parametric pension reform cannot resolve this dilemma, and that a fundamental pension reform is needed. The consensus view in the scientific debate appears to be that a funded component needs to be introduced in order to complement the existing pay-as-you-go systems, although the assessments vary in details; see, among others, Miles and Timmermann (1999), Boldrin et al. (1999), Börsch-Supan (2000), and Disney (2000).

Because even patched-up pay-as-you-go systems will have extremely low rates of return, more fundamental pension reforms entailing a significant extent of pre-funding have become not only economically but also politically more attractive (Boeri, Börsch-Supan, and Tabellini, 2001). In most countries, the political debate has moved towards augmenting existing pension systems with a funded pillar. Germany and Italy have now started to implement mixed multi-pillar sys- 
tems. Following the arguments in the previous subsection, France will have little choice but to adopt a significant extent of pre-funding as well.

Börsch-Supan (2000) and Börsch-Supan, Heiss, and Winter (2000) show that such a reform can be implemented without too high a transition burden, using a macroeconomic simulation model. In the next subsection, we present a multi-country overlapping generations model at allows for quantitative projections for the additional savings that are generated by population aging and pension reform when capital is internationally mobile. These quantitative models are important elements of our chain of arguments: pension reform is likely to occur, it can be done, and together with the direct effects of population aging, it has quantitatively important effects on the capital market.

To this end, we need to work through the implications of a realistic transition to a partially funded multi-pillar pension system. There are several reasons why it is unrealistic to model a full transition to pre-funding. First, public pension systems traditionally also have redistributive character, and redistribution is, through one mechanism or the other, always pay-as-you-go. Estimates of the share of pensions that are pure transfers range between 20 to 40 percent in Germany (mainly topped-up pensions by a minimum retirement income mechanism and pension points earned while in education or while raising children), leaving 60-80 percent of pensions available for potential privatization in a multi-pillar system. The shares are similar in France and Italy. There are also other reasons to be conservative in the degree of pre-funding. For instance, pay-asyou-go systems have a built-in insurance against inflation and secular capital market failures. For an extensive discussion of these risk aspects, we refer to Miles and Timmermann (1999).

The fundamental pension reform we consider here implements a transition towards a funded system in which the division of labor between pay-as-you-go and funded pillar is implicitly given by the policy objective to stabilize the contribution rate of the pay-as-you-go system, but to provide with all pillars today's pension replacement level (e.g., Börsch-Supan, 2000). Under this scheme, the current contribution rate is frozen, implying a decreasing replacement rate of the pay-as-you-go system. The resulting pension gap will then be filled through pre-funding.

\subsection{Quantitative predictions of the capital markets effects of aging and pension reform}


From a macroeconomic point of view, population aging changes the balance between capital and labor, in particular in industrialized countries. Labor supply is going to be relatively scarce whereas capital is going to be relatively abundant. This will drive up wages relative to the rate of return on capital, reducing households' incentive to save (if the interest elasticity of saving is positive). In addition, some fraction of the capital stock may become obsolete due to the shrinking labor force and diminishing returns to scale, making the accumulation of capital even less attractive. Loayza, Schmidt-Hebbel and Servén (2000) present empirical evidence for the negative long-run effect of increasing old-age dependency ratios on saving.

In the short term, that is, while dramatic changes in the age structure are underway, the behavior of the savings rate is quite different - our simulations show that savings rates increase until about 2020, and the capital held by households in aging countries will be (much) higher than currently well into the second half of this century. In addition to these domestic effects, there are differences in timing of population aging across countries - not only between industrialized countries and developing countries, but also within the group of industrialized countries as well. Capital exports from fast-aging countries to those countries with a more favorable age structure can reduce aging problems in industrialized countries, but cannot solve them entirely (Blommestein, 1998; Reisen, 2000). There is also some empirical evidence that the mechanism of age-induced capital flows is already at work (e.g., Higgins, 1998).

In order to quantify the macroeconomic effects of population aging and pension reform, Börsch-Supan, Ludwig and Winter (2001) have developed a dynamic simulation model which is a version of the overlapping generations model as introduced by Auerbach and Kotlikoff (1987). Overlapping generations models have been used extensively to study the effects of population aging on social security systems, a purpose for which they are well suited since they are based on households' and firms' optimal reactions to movements in the demographic structure and public policy measures. ${ }^{3}$ While the model by Börsch-Supan, Ludwig and Winter (2001) is a very stylized representation of the real world in many respects, they take great care to capture the firstorder effects of demographic change on capital markets. Two features of their model are therefore

\footnotetext{
3 Recent examples include De Nardi et al. (2000) and Kotlikoff et al. (2000) for the United States, Miles (1999) for Great Britain and Fehr (2000) and Börsch-Supan, Heiss and Winter (2000) for Germany. Miles and Iben (2000) present a comparative analysis of pension reform schemes for the United Kingdom and Germany based on an overlapping generations model.
} 
of particular interest. First, the model consists of several countries with potentially different aging processes, and it allows capital mobility. Thus, international capital flows induced by differential aging can be explained endogenously. Second, demographic projections used in this 75generation model are very detailed. For Germany, these projections are taken from Birg and Börsch-Supan (1999), and for the other world regions from the United Nations' World Development Prospects (1998 revision).

The following projections focus on Germany with its generous pension system, a severe aging problem and persistent calls for a fundamental pension reform that implies a shift to more pre-funding. To separate the direct effect of population aging and the additional effect of pension reform, we present all projections for two scenarios, the current pay-as-you-go system and under a fundamental pension reform. These scenarios are polar cases, and they are both counterfactual: As we have discussed in the previous section, the current system is politically unsustainable and cannot survive at its current level of generosity, while the pension reform that was passed in February 2001 is by no means as fundamental as the one we consider in our simulations. Even the pension reform we analyze in our simulations does not imply a full shift to a funded system, but only a partial transition with about one third of retirement income coming from the funded pillar. In any case, the eventual outcome of pension reforms might well be somewhere between our scenarios. Analyzing these polar cases is, however, helpful since they show that a good portion of the capital market effects of population aging would arise even without a fundamental pension reform. In addition to the two reform scenarios, we also consider three alternative capital mobility scenarios: investment only within Germany (the closed-economy case), investment in the EU countries, and investment in the OECD countries. ${ }^{4}$

The projects depicted in figure 2-1 show that (i) aggregate savings rates rise substantially even under the current pay-as-you-go system, and (ii) aggregate savings rates under a fundamental pension reform would be higher than under the present system. For example, in the year 2035, when the peak of the aging problem occurs, savings rates are projected to be very low under the current PAYG system. Conditional on the capital mobility scenario, the aggregate household savings rate declines from currently around 12 percent (1998) to between 8 and 9 percent, an effect 
that is due to aging. In contrast, under a fundamental pension reform, the aggregate saving rate settles at around 9.3 percent under the assumption of perfect capital mobility within the EU. These projections show that optimal life-cycle behavior generates additional saving under a fundamental pension reform - it is not the case that additional retirement saving crowds out other saving totally, as often claimed. Our projections indicate a substitution of about one third, leaving two thirds to new saving. ${ }^{5}$ It is important to note that all variations of the aggregate saving rate shown in figure 2-1 are in the range of the historical variation in German household saving rates. Also, we should point out that a recent empirical cross-country study by Samwick (2000) demonstrates that the direct effect of fundamental pension reforms on savings rates is negative. It is therefore important to stress that the increase in the saving rate predicted by our model for the next few decades is primarily due to population aging (much more dramatic than in other countries' historic experience), and that the pension reform we consider exacerbates the transitory positive effect of population aging on aggregate savings rates.

Next, we aggregate savings to obtain a country's foreign position and capital stock. Figure 2-2 shows projections of the total capital stock under the current pension system. A first observation is that the variations in the time path of the aggregate capital stock are by far less pronounced in an open economy. These waves are caused by the alternating dominance of demographic effects and of growth in labour productivity. The economy gradually accumulates capital until the peak of the aging process is reached in 2030, since in the beginning the tendency to disinvest in capital due to the aging process is dominated by the modest increase in labour force participation and technological progress. After 2030, when the aging process has almost reached its peak, the capital stock decreases if Germany is a closed economy. In the open economy case, the growth of the capital stock almost disappears, but the growth rate never becomes negative. In the open economy scenarios, the German capital stock increases to about 144 (140) percent of its current value if the capital is freely mobile within the OECD (EU) relative to 138 percent if Germany is a closed economy. Under a fundamental pension reform, the decrease in the German capital stock in the closed economy scenario, that is caused by aging, is less pronounced since more capital is

\footnotetext{
4 In all projections reported here, we assume that all other countries maintain their current pension systems. Börsch-Supan, Ludwig and Winter (2001) also consider a scenario in which other countries implement fundamental pensions reforms as well.

5 The right panel of Figure 3-1 shows discrete adjustment in behavior that occur when the pension reform takes place, or is announced.
} 
accumulated as a result of the pension reform. The increase of the aggregate capital stock is now higher than in both the open economy scenarios. This indicates that, under the pension reform, relatively more capital is invested abroad.

Finally, we consider the general equilibrium effects on the return to capital. As can be seen from figure 2-3, the return to capital in the closed economy scenario decreases by 0.5 percentage points between the years 2012 and 2026, an effect caused by aging. This decrease is only around 0.3 percentage points when capital is freely mobile within the European Union, and only 0.1 percentage points in the OECD scenario. The pension reform leads to a reduction in the rate of return to capital caused by the higher supply of capital. In the closed economy scenario the rate of return is reduced by 0.5 percentage points in 2050 relative to the rate of return in the current pension system. This is much less than often claimed in the public debate. Moreover, the decrease in the rate of return to capital reduces to only 0.12 percentage points if capital is freely mobile within the EU. In the OECD scenario, the yield difference almost disappears; it is as high as 0.04 percentage points. This suggests that the additional savings induced by a pension reform should be invested internationally, not only for reasons of risk diversification, which we cannot show in our deterministic model, but also for sake of higher returns that are possible in the open economy. It is also important to note that substantial positive effects of capital mobility occur even in a very modest capital mobility scenario. Indeed, Börsch-Supan, Ludwig and Winter (2001) show that there is virtually no difference between the OECD scenario and a scenario where we allow for perfect capital mobility in the entire world.

The transition costs of such a reform are relatively modest; we return to this issue in the concluding section of this paper. The main result for the next step of analysis is that the amount of additional saving generated by population aging and pension reform is substantial. Whether or not this new retirement saving crowds out other savings or not - this is the subject of the following section -, the share of pension funds in total productive capital would become substantial, and it is likely that this will change the nature of the underlying capital markets. This link between pension reform and capital markets will be subject of Section 4 .

\section{A closer look at life-cycle saving and portfolio decisions}


The simulation model we used in the previous sections was based on a very stylized view of households' life-cycle savings behavior, but it allows to get the aggregate effects right. In this section, we take a closer look at households' portfolio choice patterns. We show that they are strongly influenced by public pension systems, and we make a prediction of how they are likely to change when public pension systems become less generous due to population aging.

Specifically, we claim that the saving patterns in France, Germany and Italy reveal that saving for retirement plays only a small role in these countries relative to other savings motives. Turning this argument around, we anticipate a distinct change in savings patterns in France, Germany and Italy in wake of a fundamental pension reform because it revives the retirement savings motive. In particular, a partial transition to a funded pension system is likely to change how saving is related to age and how households select their portfolios. This is, of course, the timehonored question (Feldstein, 1974; Barro, 1974) whether pay-as-you-go pension systems crowd out private saving. We give it a new tack by looking at the life cycle pattern of savings in France, Germany and Italy.

As a point of departure, it is important to realize that the pay-as-you-go financed public pensions in France, Germany and Italy have very high replacement rates. They generate net retirement incomes that are approximately 70 percent of pre-retirement net earnings in Germany and France, and may even exceed 100 percent in Italy. ${ }^{6}$ In addition, the public pension systems in France, Germany and Italy provide generous survivor benefits that constitute a substantial proportion of total unfunded pension wealth, and disability benefits at similar and often even higher replacement levels than old-age pensions. As a result, public pensions are by far the largest pillar of retirement income in these countries and constitute more than 80 percent of the income of households headed by persons aged 65 and older, while funded retirement income, such as asset income from private saving or firm pensions in which the employer saves on behalf of the worker, plays a much smaller role than, e.g., in the Netherlands or the Anglo-Saxon countries. It is not straightforward, however, to infer from these differences between the pension systems the level of saving

6 This replacement rate is defined as the current pension of a retiree with a 45 -year average earnings history divided by the current average earnings of all dependently employed workers. This concept is different from the replacement rate relative to the most recent earnings because these are usually higher than the life-time average. Because the Italian system uses only the last 5 years as a pension base and applies a statutory replacement rate of $80 \%$ to that base, the replacement rate with respect to the average lifetime income often exceeds $100 \%$. 
rates in the different countries - too many other factors, from real estate prices through the organization of financial markets, are likely to confound such a comparison. We therefore first look at life-cycle saving patterns, then at portfolio composition.

\subsection{Life-cycle saving patterns}

Constructing life-cycle savings profiles is not trivial unless one has long time-series of individual households - such data, however, is not available. Moreover, comparing saving observations in different countries is tricky as variable definitions tend to vary greatly across countries. Fall (2001), Börsch-Supan, Reil-Held, Rodepeter, Schnabel and Winter (2001), and Brugiavini and Padula (2001) have analyzed life-cycle saving patterns in France, Germany and Italy within a comparable framework. They use repeated cross-section data to separate age from cohort effects, and employ comparable variable definitions and data sources as part of the International Savings Comparions Project (Börsch-Supan, 2001). Their central finding is that the observed ageconsumption profiles in France, Germany and Italy are rather flat and show no dissaving in old age. This is evident from Figure 3-1 which shows, by age group, median saving rates in these three countries.

The samples employed in this exercise do not include elderly living in institutions, so there might be a bias towards households which are less likely to dissave. Börsch-Supan (1992) shows for Germany that this bias cannot explain the observed pattern at the prevailing rates of institutionalization. His selectivity correction only reduces the upturn of saving rates at the oldest age categories. The saving profiles in figure 3-1 are also robust to several other specification and measurement alternatives; the reader is refereed to Börsch-Supan (2001).

There are several elements explaining these saving patterns, all linked to the pension system. First and foremost, the high replacement rates of the public pension systems in these countries make additional private retirement income largely unnecessary as pointed out above. Thus, saving for retirement, the only motive under the pure life-cycle hypothesis, cannot be the main savings motive. In fact, Schnabel (1999b) shows that in Germany retirement is not a time of scarce resources for current generations of pensioners. Rather, due to rising productivity and double indexation of pensions to gross wages, retirement income has been above average income 
during working life for cohorts born before $1930 .^{7}$ Similar arguments hold for France and Italy, where pensions provide even higher replacement rates than in Germany (Boeri, Börsch-Supan, and Tabellini, 2001). If other saving motives, such as precaution and intergenerational transfers, are more important than retirement saving, age-saving profiles are likely to be much flatter than under the famous textbook life-cycle hypotheses which predicts saving in young and dissaving in old age. This explanation also nicely fits into the work by Jappelli and Modigliani (1998) who argue that the main mechanism for retirement savings - the only savings motive under the textbook life-cycle-hypothesis - is the pay-as-you-go system. If one, as they do, adds contributions to these pension systems to savings and subtracts benefits from them, the familiar textbook humpshaped saving profiles return indeed.

Another and related element explaining why the elderly do not appear to dissave is brought forward by Börsch-Supan and Stahl (1991), Börsch-Supan (1992), and Schnabel (1999b). They find that after retirement, consumption remains low and there are high inter vivos transfers as well as positive savings. Börsch-Supan and Stahl (1991) argue that due to deteriorating health conditions, the elderly are simply less able to spend as much as they would need to make saving negative. A complementary explanation is simply habit persistence in old age. Again, root cause is the high annuitized pension income which cannot be borrowed against even if the decline in health were anticipated.

While it may be suggestive and plausible that the rather flat saving profiles in France, Germany and Italy are due to the dominant public pension systems in these countries, the argument is vulnerable because we lack a counterfactual. The most appropriate counterfactual would be French, German and Italian data from times when these countries had no pay-as-you-go systems. Of course, we do not have such data. Another alternative are international comparisons across countries with differing mixtures of pay-as-you-go and funded pension systems. Poterba (1994) provides a comparison of six OECD countries. It suggests that the textbook hump-shaped life-cycle savings pattern is most pronounced in the U.S. and Canada where the replacement rates of the public pay-as-you-go pension systems are lower than in continental Europe. These findings, however, may be confounded by cohort effects. More significant is therefore the comparison with

7 This holds for (equivalized) household income and even more so for per capita income. 
the cohort-corrected saving rates in the Netherlands 1993, computed by Alessie and Kapteyn (2001) as part of the International Savings Comparison Project mentioned above. The Netherlands have, as opposed to France, Germany and Italy, only a small base pension provided by their pay-as-you-go public pension system, with benefits linked to the minimum wage. All additional retirement income in the Netherlands has to be provided by (mandatory) savings plans, commonly provided through occupational pension plans. Figure 3-1 shows that the median Dutch household has a much more pronounced hump-shaped life-cycle savings profile than the median French, German and Italian households. Moreover, figure 3-1 shows dissaving among the elderly as they draw down their mandatory saving accounts. Of course, we are aware that this is a comparison between four data points only. We are in the process of collecting similar profiles also for the UK and the US.

If indeed most of the saving patterns currently observed in France, Germany and Italy are caused by their pay-as-you-go pension systems with their generous retirement benefits, we should expect distinct changes in saving patterns in the future. As described at the end of Section 2, a pension reform towards a multi-pillar system with a substantial portion of funded retirement income will revive the retirement motive for saving. In fact, these systems will look very similar to the current Dutch system. Hence, it is likely that saving rates among the young will increase (to accumulate retirement savings), and saving rates among the elderly will decline sharply (because they will dissolve their retirement savings).

The simulation results in Section 2 also give us an order of magnitude for those effects. To the extent that all the induced retirement saving by a multi-pillar pension reform is new saving, the net saving rate of the average German household in mid age would increase by about 4 percentage points (from 11 to 15 percent). The saving rate would decrease by in old age, when retirement accounts are used for consumption, by about 6 percentage points, from 4 to -2 percent). Portfolio composition would also change, see the next subsection.

Note that some substitution between these new saving for old age and other savings is likely. This will decrease the effect of a fundamental pension reform on the overall household saving rate, but will increase the effect on portfolio composition. We do not know the precise magnitude of such effects. Precautionary saving may even increase, while saving for intergenerational transfers is more likely to decrease in response to introducing a higher degree of self- 
provided retirement income. The overlapping generations model of section 2, calibrated to German data and combined with a bookkeeping model of the new multipillar pension system, yields a rough estimate of substitution. It amounts to about one third, i.e., one third of the new saving will be crowded out while two thirds will be net additions to the capital stock.

\subsection{Portfolio composition}

The German pay-as-you-go public pension system appears also to have shaped the composition of household financial wealth. Table 1-4 displays portfolio choice in Germany, as analyzed using household data from the 1993 wave of the German Income and Expenditure Survey, drawn from Börsch-Supan and Eymann (2001) as part of a parallel internationally comparative exercise lead by Guiso, Jappelli and Haliassos (2001). The important role of whole life insurance can be seen from the fact that, in 1993, its share in total financial wealth was about a third. The central reason for the important role of whole life insurance in German households life-cycle savings decisions is its favorable tax treatment (see Brunsbach and Lang, 1998, and Walliser and Winter, 1999). At the household level, financial saving in whole life insurance is more important than saving in stocks and bonds. ${ }^{8}$ A substantial portion of this saving is used as a device to finance homeownership. Pension funds do not even appear in the aggregate statistics, so small is their share, very different from The Netherlands and the United Kingdom (Guiso, Jappelli and Haliassos, 2001).

The important role of whole life insurance is also significant for financial markets, as lifeinsurance companies are not allowed to invest significantly in stocks, which in turn has been one of the main reasons for thin capital markets in Germany (see Deutsche Bank Research, 1996). As we discuss in Section 4, these restrictions will become less important because of increased availability of alternative products and the resulting increase in competition for retirement saving.

This portfolio composition is likely to change under a partial transition to a multi-pillar system. We again use the simulation results for Germany. If there were no substitution between new retirement saving and current saving, the net household saving rate would increase by about 4 percent, as mentioned in the previous subsection. If all of this would be channeled into pension

8 The majority of stocks and bonds are bonds. Stocks are less than 10 percent of the average household portfolio. 
funds, pension funds would amount to between 15 and 18 percent of households' portfolios, comparable to the United Kingdom, the U.S., the Netherlands and Switzerland. Substitution between new retirement saving and current saving would increase this share, although part of new retirement saving may also be made through whole life insurance given its preferential tax treatment. Households' direct and indirect exposure to stock markets then depends on future investment decisions of life insurance companies who only recently began to increase their portfolio share of stocks. Judging from the international experience in countries as diverse as the United Kingdom, the U.S., the Netherlands and Switzerland, a more prominent role of equities on the

supply side of the capital markets seems very likely when more of the retirement income will be pre-funded in France, Germany and Italy.

We finish this section with one important hint for policy makers: if they want to understand future saving volumes and their allocation and design their policies accordingly, we researchers need better data. If they want forecasts that are more precise than the qualitative trends derived from our simulation model, we need longitudinal data on portfolio choice and saving behavior.

\section{How strong capital markets enhance productivity and growth}

In the previous sections, we have shown that in aging countries with predominant pay-asyou-go pension systems such as Germany, population aging, together with an increase in prefunding of pension schemes, (i) raises aggregate saving and the balance of assets held by private households, and (ii) changes the portfolio composition of private households, with an increase in the share of risky assets that offer higher expected returns. We now investigate how these changes may affect productivity and economic growth via their impact on financial markets.

Our argument proceeds in three steps. First, we briefly review the literature on the relationship between financial market conditions and economic growth, and we present some new suggestive evidence for the impact of stock market capitalization and the size of pension funds. Next, we investigate one channel through which capital market conditions might have affected economic growth over the last two decades or so. Specifically, we show that the poor productivity performance of firms in countries such as Germany, France and Italy relative to the United States, 
the current leader in productivity growth among the large industrialized countries, is related to poor corporate governance. Finally, we discuss the potential benefits of an increasing role of active investment and pension funds in countries with weak corporate governance structures.

\subsection{Financial market conditions and growth}

We are not the first to argue that the development of financial markets is an important factor in explaining the sources of productivity and economic growth; see Levine (1997) for an extensive review of this literature. Following Levine (p. 691), one can distinguish five functions of the financial system: (i) to facilitate the exchange of goods and services; (ii) to facilitate the trading, hedging, diversifying, and pooling of risk; (iii) to mobilize savings; (iv) to allocate resources; (v) to monitor managers and exert corporate control. The last two of these functions are of particular relevance for the present paper.

In our analysis of the potential effects of population aging and pension reform on economic growth, we focus on the role of overall market liquidity and the size stock markets. While theoretical models show that banks can generally perform the basic functions of the financial systems in similar ways as stock markets, recent experience raises doubts that bank-based systems have performed as well as market-based systems, at least over the last two decades (see section 4.2 below). ${ }^{9}$ Among the many theoretical models that analyze the role of stock markets for resource allocation and corporate governance, we mention only a few (Levine, 1997, lists many more). Grossman and Stiglitz (1980) and Holmstrom and Tirole (1993) show that as markets become larger and more liquid, market participants have more incentives to acquire information about firms. Jensen and Meckling (1976) and Jensen and Murphy (1990) show that linking manager compensation to stock performance helps to align the interests of managers with those of owners, and that takeovers are easier in well-developed stock markets, thus improving corporate governance.

The empirical literature that explores these mechanisms has grown dramatically over the last few years. In addition to the survey by Levine (1997), see Beck, Levine, and Loayza (2000) for a helpful review of very recent work in this area. Again, we mention only a few results that are

\footnotetext{
9 Edwards and Nibler (2000) provide a more favorable view of the role of banks and ownership concentration in Germany.
} 
of particular relevance to our argument. In a careful time-series study with aggregate data, Neusser and Kugler (1998) demonstrate that financial sector development predicts GDP growth and, in particular, total factor productivity. Levine and Zervos (1998) report that stock market liquidity is positively and robustly correlated with contemporaneous and future rates of economic growth, consistent with the view that a greater ability to trade ownership of an economy's productive technologies facilitates efficient resource allocation, physical capital formation, and faster economic growth. Levine and Zervos also find no negative impact of stock market liquidity, international capital market integration, or stock return volatility on private savings. Similar findings have been obtained by Rajan and Zingales (1998) who compare industrial sectors across countries, arguing that financial development reduces the costs of external finance to firms. Wrugler (2000) confirms that financial markets play an important role in the capital allocation process. He reports that the efficiency of capital allocation is positively correlated with the degree of legal protection of investors (i.e., in Anglo-American, market-based financial systems). In particular, Wrugler argues that market-based systems are more successful in limiting overinvestment in declining industries. Finally, using cross-country panel data, Beck, Levine, and Loayza (2000) and Levine, Loayza, and Beck (2000) show that financial intermediaries exert a large, positive impact on total factor productivity and GDP growth.

One frequently made objection against a causal interpretation of the relation between financial markets development and economic growth is that financial development is only a leading indicator of growth, i.e., that expected of economic growth causes improvements in the financial sector. Such doubts have been addressed with disaggregate studies at the firm and industry levels, including some of the more recent work we mentioned above. It is our reading of the literature that the well-documented positive effect of financial market development on economic growth is not due to reversed causality.

To illustrate the relevance of stock market development and pension funds for economic growth and productivity, we present additional empirical evidence based on a panel of 24 OECD countries. ${ }^{10}$ Data on GDP growth rates and stock market capitalization for the period 1998-97 are

10 These 24 countries are: Australia, Austria, Belgium, Canada, Denmark, Finland, France, Germany, the United Kingdom, Greece, Ireland, Iceland, Italy, Japan, Korea, Luxembourg, the Netherlands, Norway, New Zealand, Portugal, Spain, Sweden, Switzerland, and the United States. 
from the OECD's World Development Reports (various issues); with a few missing items, the number of observations is 211. In addition, we have data on pension funds for 1996 from Bank of International Settlements (1998, table V.5) and for 1999 from Merrill Lynch (2001, table 10).

In table 4-1, we report a Granger causality analysis for the relationship between stock market capitalization and economic growth. These regressions confirm that after controlling for fixed effects, there is a significantly positive relation between contemporaneous values of stock market capitalization and the annual growth of GDP. The relation between lagged stock market capitalization and current GDP growth is also positive and significant, while future stock market capitalization does not significantly predict GDP growth.

To highlight the relevance of this result for our argument, it is instructive to look at some countries in more detail. Figure 4-1 displays for ten countries the combination of stock market capitalization (relative to GDP) in 1997 and the average annual growth rate over the 1990-98 period. It is striking how four countries with predominant pay-as-you-go pensions systems (Italy, Germany, France, and Spain) cluster at low levels of stock market capitalization and relatively low GDP growth, compared with the cluster of three countries (the Netherlands, the UK and the US) with funded pension systems, high levels of stock market capitalization, and relatively higher growth rates. Even though the difference in growth rates might not appear to be large on first sight, the compound effect of, say, a 0.5 percentage point growth rate difference over ten years is economically quite significant. Needless to say, we do not claim that this figure alone proves causality, and we haste to add that the positions of the remaining countries in this figure (Japan, Ireland, and Sweden) indicate that there are many other factors than stock market capitalization that affect economic growth.

A similar picture arises if we look at the relation of pension fund assets (relative to GDP) and the average annual rate of GDP growth over the 1990-98 period; see figure 4-2. ${ }^{11}$ This is not surprising, since the relationship between pension fund assets and stock market capitalization is itself relatively tight (with a correlation of 0.603 in the 1996 cross-section). Finally, we consider at the relationship stock market capitalization and total factor productivity. Total factor productivity growth is one of the major sources of GDP growth (Hall and Jones, 1999). We should expect

11 Pension fund assets are for 1996 for Japan and the United states, and for 1999 for the remaining eight countries. 
that countries with deeper capital markets have relatively higher levels of total factor productivity. Figure 4-3 shows, for the same set of ten countries, the relationship between stock market capitalization and total factor productivity, the latter computed from data reported in Hall and Jones (1999). Here, the relationship is not very tight, but there is a positive cross-sectional correlation of 0.387 .

We interpret the evidence presented in this section, together with the wealth of results reported in the literature, as an indication that there is indeed a relation between the depth of financial markets (i.e., stock market capitalization and size of pension funds) and aggregate economic performance. There are, of course, numerous concerns related to small sample sizes and causality, and we refrain from giving these results a causal interpretation. Rather, we present additional firm-level and cross-country evidence in the next section that suggests that there is indeed a chain of causality between capital markets, corporate governance, and long-term economic performance.

\subsection{Potential reasons for long-term performance differences}

In order to analyze the sources of long-run differences in productivity across countries, Börsch-Supan (1998b) combines two sources of variation, across countries and across companies, using data from company benchmarking studies by McKinsey Global Institute (1996) for West Germany, Japan and the United States. He estimates rates of return on investment and investigates the contribution of capital - more precisely, capital management and capital utilization - to total factor productivity. Notwithstanding substantial variation across companies and industries, the market sectors of West Germany and Japan had significantly lower rates of capital utilization in the early 1990s and created less productive capacity per unit of physical assets than the United States did. Börsch-Supan shows that these low rates of capital utilization were only partially due to high labor costs relative to capital, leading to high capital intensity at short work hours. More important for the aggregate result of poor capital productivity were the many cases in which management did not focus on how productively they were using their assets. Conversely, a focus on financial performance, especially prevalent among U.S. firms, did create a clear performance objective that was generally aligned with productivity. 
In order to address Porter's (1992) criticism of short-termism, Börsch-Supan (1998b) looked at the long-run rates of return. Over the 1974 to 1993 period, U.S. financial performance was significantly better than in Germany, and on average better than in Japan. He calculated financial performance by relating the pay-outs from the corporate sector (interest, dividends and capital gains) to the inflows into the corporate sector (debt and equity) through the corresponding internal rate of return, including the initial and final stock of financial wealth. ${ }^{12}$ Results are displayed in figure 4-4. For the 20 years between 1974 and 1993, the annualized aggregate rate of return was 9.1 percent in the United States compared to 7.4 percent in Germany. After 1990, U.S. rates of return also exceeded Japanese returns. These estimates are robust with respect to changes in definition and computation period for the U.S.-German comparison, while the high income share to capital in the early 1970s and the Japanese bubble at the end of the 1980s make the U.S.-Japan comparison subject to higher variance. ${ }^{13}$ These differences in the long-run rates of return do not support the view by Porter (1992) that short-termism in the United States compromises long-run financial performance.

These long-run results by Börsch-Supan (1998b) on cross-country differences of rates of return confirm earlier short-run estimates by DeJong (1995), and they have been confirmed by Mueller and Yurtoglu (2000). These differences in rates of return are also reflected in the persistence of total factor productivity differences between Germany and Japan versus the United States (about 15 percent lower in Germany, 40 percent in Japan for the 1991--1996 period). While the returns to invested capital are, trivially, linked to capital productivity, the link to total factor productivity needs more attention because in theory, differences in labor productivity might offset opposite differences in capital productivity. However, this is not the case in practice - just the opposite: Labor and capital productivity are positively correlated across countries and industries (McKinsey Global Institute, 1996), generating the positive correlation between the returns visible in figure 4-4 and total factor productivity.

12 The computation is based on the flow of funds data in the OECD National Accounts, augmented by capital gains from Standard and Poor 500 (U.S.); DZ-Index of all publicly listed companies (Germany); Index of all Section 1 companies listed on the Tokyo Exchange (Japan). For details, see MGI (1996).

13 However, comparisons that cover the full cycle of bubble boom and burst, i.e., from 1992 onward, and that exclude the very early 1970s, when Japan's capital market development was not comparable to the U.S. and Europe, yield a return difference between U.S. and Japan that is even larger than that between the U.S. and Germany. 
Needless to say, there are many other reasons for international differences in financial performance and productivity in addition to corporate governance. A prime candidate is the extent of competition in product markets. However, there may be important interactions with corporate governance. Börsch-Supan (1998b) and McKinsey Global Institute (1996) argue that lower productivity can be traced to a self-reinforcing interaction of weaker product market competition and weaker capital market pressures in West Germany and Japan, which in turn are exacerbated by government regulation and ownership. Januszewski, Köke and Winter (1999) investigate whether such interactions exist in Germany. Using a panel with data on almost 1000 German firms over the 1986-94 period, they find that those industries which are characterized by more intensive product market competition tend to see higher productivity growth rates, controlling for the effects of corporate governance. Similar findings have been obtained by Nickell et al. (1997) for the U.K.

In summary, a corporate governance system with a highly concentrated ownership of capital by banks and cross-holdings (as in Germany, other continental European countries and in Japan) appears to generate lower short- and long-run returns to invested capital as well as lower total factor productivity than the Anglo-Saxon system with its dominance of institutional investors. This raises the issue of the role of corporate governance structures in Germany.

The ultimate owners of capital are households (and the state). However, industrial crossholdings and bank ownership weaken this link. This effect is particularly pronounced in Germany: German households (and, on behalf of households, institutional investors other than banks) hold a very small share of productive capital. In 1996, the corresponding share was 11.4 percent in Germany while it was 59.8 percent in the United Kingdom and 43.4 percent in the U.S., respectively. In turn, cross-holdings of German banks and non-financial companies among large firms are very common in comparison to the Anglo-Saxon countries. 46.8 percent of all shares (measured as gross capitalization) are held by banks and non-financial companies while this share is only 1.5 percent in the United Kingdom and 2.5 percent in the U.S., mainly due to legal restrictions and tax treatment. Wenger and Kaserer (1998) estimate cross-holdings to be at least 27 percent of gross capitalization in 1994 and presumably much more. Adams (1999) provides a detailed analysis of how current legal arrangements allow managers to hide the structure of crossholdings from the public. Adams concludes that "it is impossible to discover the ownership and 
control structure in Germany from the mandatory accounting publications" (Adams 1999, p. 80). Becht and Boehmer (1999) report that 85 percent of all publicly traded firms have a dominant shareholder who controls more than 25 percent of the voting rights, in most cases a bank or a non-financial company. The concentrated control structure is pronounced by the German proxy voting system which gives the banking system convenient access to the votes of dispersed owners in the general shareholder meetings.

While it is undisputed that equity ownership and control rights are highly concentrated in Germany, there is less agreement on the impact of the concentrated ownership of shares by banks and non-financial companies on firm performance. Wenger and Kaserer (1998) provide evidence that the degree of bank involvement is negatively correlated with firm performance, using a sample of large German companies covering 56 percent of market capitalization. This study has credibility because it a common methodological problem encountered in the empirical debate: Many effects are poorly identified in historical data due to the absence of any clear cut natural experiment, and hence most studies lack a counterfactual. Germany has never experimented with large institutional investors, and its corporate governance system has been quite stable over the last decades. Wenger and Kaserer come fairly close to using proper exogenous variation in corporate governance because they use a difference-in-difference approach to link changes in returns to changes in the supervisory board for companies with high and low bank involvement. Edwards and Nibler (2000) provide a slightly more favorable assessment of German banks' role in corporate governance. They report some evidence that concentrated ownership has positive effects on firm performance. To the extent that they find positive effects of concentrated ownership, they are not particularly related to the role of banks. In some cases, concentrated ownership has even negative effects.

As we argued before, because of population aging and fundamental pension reforms, and because of households' optimal reaction, countries such as Germany are likely to move from predominantly bank-based financial systems towards a more prominent role of investment and pension funds. The evidence reviewed in this section suggest that this should have a positive impact, but it was primarily based on the observation that a bank-based system does not provide good corporate governance in many cases. The next section discusses why investment and pension funds might actually improve corporate governance. 


\subsection{Active pension funds, corporate governance and firm performance}

Pension funds, and investment funds more generally, play almost no role in corporate governance in most continental European countries. As reported by the Bank for International Settlements (1998), in 1996 pension fund assets represented only 3 percent of total GDP in Germany and 4 percent in Italy, while in the U.S. and the U.K., the shares are 57 percent and 77 percent, respectively (see table 1-2). Götzfried (1998) presents a more detailed analysis of the role of pension funds in major European countries. His results are based on a survey conducted by Eurostat in 1997. As might be expected, the number of independent pension funds is high in those countries that rely heavily on funded pension schemes, i.e., the Netherlands and Switzerland (there are no comparable data for the U.K.). In contrast, the number of independent pension funds in Germany is extremely small. At the same time, Germany has the largest number of firmspecific pension plans among those European countries covered, but in terms of their investment behavior, these are very different from pension funds in the narrow sense.

There are several reasons for these differences in the economic role of pension funds. Again, we take Germany as an example, although similar arguments can be made for other continental European countries as well. First, and most importantly, the majority of pension income is provided by the public pay-as-you-go pension system, as has been described in Section 3. Thus, few households invest in pension funds in the first place. Second, mainly due to tax advantages, individual retirement saving is channeled into whole life insurance. Life insurance companies are legally barred from investing more than a small part of their portfolios in stocks - up to about 30 percent of assets for traditional whole life insurance according to life insurance regulations, but much less in practice. ${ }^{14}$ Finally, assets that are accumulated for funded firm pension schemes are currently not invested in the capital market, but are set aside as capital reserves in firms' balance sheets, again because of legal and tax reasons. Even to the extent that these funds are invested in other firms, they are likely to contribute to the network of cross-holdings. As a result of these institutional arrangements, Germany has few institutional investors and stock market capitalization is low by international standards (see table 1-2 above).

14 In Germany, insurance companies have recently started to offer other life-insurance products which allow heavy investment in risky assets such as stocks in recent years, but until now, they claim only a small share of the market. 
Given the small role that pensions have historically had in countries with pay-as-you-go pension systems, we cannot provide empirical evidence based on past experience. Rather, we discuss how pension funds influence corporate governance in those countries in which they already play a major role. To understand pension fund investment and performance, it is useful to first think about pension funds in a world with complete markets and no agency problems. Coggin et al. (1993) note that if one accepts the efficient market hypothesis, "all active investment management activity is futile" (p. 1040), and the optimal choice for a pension plan would be to invest in a passively managed market index fund. Few people, however, would believe that financial markets are efficient - and managed pension funds do exist. But do actively managed pension funds really perform better than a passively managed index fund? In their empirical analysis of U.S. pension funds, Coggin et al. (1993) find that after adjusting returns for risk, some fund managers outperform the market while most do not, a result that has been replicated in many similar studies.

An important way for pension fund managers to improve the performance of their funds is to take an active role in improving corporate governance. This brings us to the second issue: The role of large shareholders in disciplining management and the effectiveness of shareholder activism are central to understanding the macroeconomic consequences of an increase in pre-funded pensions. The basic theoretical argument has been made, for example, by Pound (1988): Institutional investors such as pension funds that have no business relations with a firm can do a better job in disciplining management.

There is a large number of studies which try to evaluate the effectiveness pension fund activism. Black (1998) surveys the literature on large shareholder and pension fund activism and concludes that pension fund interventions are generally ineffective. However, there are also quite a few studies which indicate that pension fund activism has beneficial effects and that agency problems are not a major concern in practice. For example, Del Guercio and Hawkins (1999) study shareholder proposals of the largest, most active funds from 1987 through 1993. They conclude that pension funds are successful at monitoring and promoting change in target firms, and they do not find evidence to support that funds have other motivations than value maximization. This result can be interpreted as indicating that agency problems might not be a major concern in practice. 
Several empirical studies concentrate on the best-known example of an active pension fund, the California Public Employees' Retirement System (CalPERS), the largest public pension fund in the U.S. and third largest in the world with total assets over 164 billion US Dollar in 1999. Over the last decade, CalPERS has been at the forefront of shareholder activism, with an explicit goal "to efficiently and effectively manage investments to achieve the highest possible return at an acceptable level of risk." To this end, CalPERS reviews the performance of the U.S. companies in its stock portfolio on a regular basis and identifies those that are among the lowest long-term relative performers. This review process results in a list of companies that are publicly identified as a "CalPERS focus company". In 1999, this list covered nine companies. Among other interventions, CalPERS filed 65 shareholder's proposals in order to improve firm performance of its focus companies during the 1987-1998 period. The average annual rate of return was $13.2 \%$ over these ten years. ${ }^{15}$ Nesbitt (1994) reports weak evidence that CalPERS interventions affected stock prices of targeted firms positively. Smith (1996) analyzes 51 firms out of the 78 targeting events of CalPERS over the 1987-93 period. He finds that shareholder wealth increases for firms that adopt or settle, and decreases for firms that resist changes proposed by CalPERS. Smith concludes that "shareholder activism is largely successful in changing governance structure, and, when successful, results in a statistically significant increase in shareholder value" (p. 251).

Based on these theoretical and empirical findings about the link between active pension funds and firm performance, we expect that an increase in the volume of equity controlled by pension funds would have major effects on corporate governance in continental European countries, and thus provide positive effects on aggregate productivity. We end this section with a note of warning: While we have seen that pension funds have helped to improve corporate governance and productivity in many instances, there are also cases in which investment funds did not perform so well. A prominent example is the case of the provident funds in Southeast-Asia which have destroyed wealth, as detailed by Asher (1998). While they contributed to economic growth through a massive accumulation of capital, they did not increase total factor productivity; see also Kim and Lau (1994) and Young (1994). These two faces of the Asian miracle were of dramatic

\footnotetext{
15 These figures and statements are taken from CalPERS' internet site (http://www.calpers-governance.org). This site contains detailed information on CalPERS' investment strategy and its position on corporate governance and shareholder activism.
} 
relevance in the recent Asian crisis, and they bear several lessons for funded pension systems. In particular, the Asian experience shows the importance of competition among funds, as realized in the Anglo-Saxon countries and in Chile, and to a lesser extent in the Netherlands and Switzerland.

\section{Summary and policy conclusions}

Population aging will change saving behavior, and pension reform - an ongoing process in the core European countries - will amplify these changes. Population aging will induce an increase in savings between 2015 and 2025. Saving rates will decline thereafter. Pension reform adds to the increase and dampens the decrease even though about one third of saving for retirement will displace other saving. A higher share of saving will flow through stock and bond markets, thereby changing the nature of the capital markets in countries where stock market capitalization is low and industrial bond are rare - notably in France, Germany and Italy. Finally, there is ample evidence that the size of capital markets and productivity growth are related. There is also reason to believe that larger capital markets and actively managed investment and pension funds enhance corporate governance.

What does this mean for economic policy? First and foremost, population aging is more than adjusting pensions and the health care system. Population aging actually profoundly changes the macroeconomic balance in Europe. While this is not an entirely new insight for economists, it tends to get lost in the policy debate which over and again focuses on social policy issues in a narrow sense.

Indeed, and this is our second policy conclusion, the debate about public pension reform should be broadened accordingly. Our main argument is that fundamental pension reform - a transition from the dominant pay-as-you-go systems in continental Europe to a substantially higher extent of pre-funding - has benefits over and above those that are usually in the focus of the transition debate. Here, we have stressed benefits arising through more efficient capital markets (another channel for positive effects of pension reform on economic efficiency and growth is the reduction of labor market distortions). Such efficiency gains are potentially large enough to 
overcompensate the welfare losses created by the transition burden induced by a fundamental pension reform. They therefore significantly change the political economy of pension reform.

Our argument adds a new and important dimension to the debate of advantages and disadvantages of pay-as-you-go and fully funded pension systems. While we know that in steady state, funded pension systems are advantageous relative to pay-as-you-go pension systems whenever the interest rate exceeds the growth rate of the wage bill, we also know that this of little help in the case of an economy which already has a pay-as-you-go pension system, as stressed by Sinn (2000). Such an economy has to pay back its implicit debt which had financed pension payments to the first generation of beneficiaries, before being able to enjoy the advantages of a funded system. Paying back this implicit debt implies a consumption loss - the so-called transition burden. In a simple Solow economy with a fixed technology, the consumption loss due to the transition burden is exactly equal to the consumption gain that will be achieved through the higher capital stock in a funded pension system (Aaron, 1966). The result also holds under more general conditions, e.g., when pension benefits must be financed by distorting payroll taxes that are in proportion to pension benefits (Brunner, 1996; Fenge, 1997).

This equivalence result, however, rests on a crucial condition, namely fixed household behavior (i.e., saving rates and portfolio choice) and a fixed technology (i.e., factor productivities). We argue in this paper that these assumptions are counterfactual. We will experience changing saving rates and portfolio choices, and we will see major shifts in the allocation of capital, inducing changes in efficiency in those countries that have thin capital markets, such as France, Germany and Italy. This opens the possibility that a (partial) transition from a pay-as-you-go to a funded pension system, through its positive effects on capital markets, results in efficiency and welfare gains in spite of the transition burden.

How important is this quantitatively? Aren't these irrelevant second order effects? We believe not. In order to assess the magnitude of the potential feedback effects that must be induced by improvements in capital allocation in order to compensate for the transition burden, consider again our example of a fundamental pension reform in Germany that would imply a partial transition towards a one-third funded pension system. Using our simulation OLG model of section 2 again, we compute the utility loss implied by the transition burden of the pension reform. Figure 5-1 shows our results. Without positive efficiency effects, some generations would be net losers. 
Figure 5-1 also shows the utility gains and losses for various increases in total factor productivity. Already a relatively small transient productivity effect of just 0.2 percentage points per year makes all generations better off.

This is an important result. It must be appreciated together with the recent Economic Policy article by Boeri, Boersch-Supan and Tabellini (2001). They found that people in France, Germany and Italy are well aware that population aging will put their pension systems into crisis. A majority also agrees to a fundamental pension reform in wishing to opt out the pay-as-yousystems in favor of a mandatory partially funded system. Not too surprisingly, however, the people did not like the idea of bearing a transition burden. This is where this paper fills in: even rather small gains in the efficiency of capital allocation in the wake of population aging and pension reform suffice to compensate for this transition burden, thereby fundamentally changing the political economy of pension reform. 


\section{References}

Aaron, H. (1966): The Social Insurance Paradox. Canadian Journal of Economics and Political Science, 32, 371-374.

Alessie, R., and A. Kapteyn (2001): Household Savings in the Netherlands, Research in Economics, forthcoming.

Asher, M. G. (1998): Investment Policies and Performance of Provident Funds in Southeast Asia, Paper presented at Workshop on Pension System Reform, Governance, and Fund Management, January 1998.

Barro, R. J. (1974): Are Government Bonds Net Wealth? Journal of Political Economy, 82, 1095-1117.

Becht, M. and E. Boehmer (1999): Transparency of ownership and control in Germany. Unpublished manuscript, Université Libre de Bruxelles and Humboldt-Universität zu Berlin.

Beck, T., and R. Levine and N. Loayza (2000): Finance and the sources of growth. Journal of Financial Economics, 58, 261-300.

Birg, H., and A. Börsch-Supan (1999), Für eine neue Aufgabenteilung zwischen gesetzlicher und privater Altersversorgung. Berlin: Gesamtverband der deutschen Versicherungswirtschaft.

Black, B. S. (1998): Shareholder activism and corporate governance in the United States. In: P. Newman (ed.): The New Palgrave Dictionary of Economics and Law. London: Macmillan.

Blommestein, H. (1998): Aging-induced capital flows to emerging markets do not solve OECD's basic pension problem. In: H.J. Blommestein and N. Funke (eds.): Institutional Investors in the New Financial Landscape. Paris: OECD, chapter XVI.

Boeri, T., A. Börsch-Supan and G. Tabellini (2001), Would you like to shrink the welfare state? The opinions of European citizens. Economic Policy, 32, in press.

Börsch-Supan, A. (1992): Saving and consumption patterns of the elderly: the German case. Journal of Population Economics, 5, 289-303.

Börsch-Supan, A. (1998b): Capital Productivity and the Nature of Competition. Brookings Papers on Economic Activity, Microeconomics. 205-244.

Börsch-Supan, A. (2000): A Blue Print for Germany's Pension Reform. Paper prepared for the Workshop "Reforming Old-Age Pension Systems”, Magdeburg, 25.-26. May.

Börsch-Supan, A. and A. Eymann (2000): Household portfolios in Germany. Discussion Paper No. 00-15, Sonderforschungsbereich 504, Universität Mannheim.

Börsch-Supan, A., F. Heiss and J. Winter (2000): Pension reform, capital markets, and the rate of return. Discussion Paper No. 589-00, Institut Volkswirtschaftslehre und Statistik, Universität Mannheim.

Börsch-Supan, A., A. Ludwig and J. Winter (2001): Aging, pension reform, and capital flows: A multi-country simulation model. Discussion Paper No. 01-08, Sonderforschungsbereich 504, Universität Mannheim. 
Börsch-Supan, A., A. Reil-Held, R. Rodepeter, R. Schnabel and J. Winter (2001): The Geramn Saving Puzzle, Research in Economics, forthcoming.

Börsch-Supan, A. and K. Stahl (1991): Life-cycle savings and consumption constraints. Journal of Population Economics, 4, 233-255.

Boldrin, M., J.J. Dolado, J. F. Jimeno and F. Peracchi (1999): The future of pensions in Europe. Economic Policy, 29, 289-320.

Brugiavini, A., and M. Padula (2001), Too much for Retirement? Saving in Italy, Research in Economics, forthcoming.

Brunner, J. (1996): Transition from a Pay-as-you-go to a Fully Funded Pension System: The Case of Differing Individuals and Intragenerational Fairness, Journal of Public Economics, 60, 131-146.

Brunsbach, S. and O. Lang (1998): Steuervorteile und die Rendite des Lebensversicherungssparens. Jahrbücher für Nationalökonomie und Statistik, 217:2, 185-213.

Chand, S. K. and Jaeger, A. (1996): Aging Populations and Public Pension Schemes, IMF Occasional Papers 147, International Monetary Fund, Washington D.C.

Coggin, T. D., F. Fabozzi and S. Rahman (1993): The performance of U.S. equity pension fund managers. Journal of Finance, 48, 1039-1056.

De Jong, H.W. (1995): European Capitalism: Between Freedom and Social Justice, Review of Industrial Organization, 10, 399-419.

Del Guercio, D. and J. Hawkins (1999): The motivation and impact of pension fund activism. Journal of Financial Economics, 52, 293-340.

Disney, R. (2000): Crises in public pension programmes in OECD: What are the reform option? Economic Journal, 110, F1-F23.

Deutsche Bank Research (1996): From Pension Reserves to Pension Funds: An Opportunity for the German Financial Market. Frankfurt: Deutsche Bank Research.

Edwards, J. and M. Nibler (2000): Corporate governance in Germany: The role of banks and ownership structure. Economic Policy, 31, 239-267.

Fall, M. (2001), Household Savings in France, Research in Economics, forthcoming.

Feldstein, M. (1974), Social Security, Induced Retirement and Aggregate capital accumulation, Journal of Political Economy, 82,5, 905-926

Fenge, R. (1997): Effizienz der Alterssicherung. Frankfurt: Physica-Verlag.

Grossman, S. J. and J. E. Stiglitz (1980): On the impossibility of informationally efficient markets. American Economic Review, 70, 393-408.

Gruber, J., and D. Wise (1999): International Comparison of Social Security Systems. Chicago: The University of Chicago Press.

Guiso, L., T. Jappelli and M. Haliassos (2001): Household Portfolios. Cambridge, Mass.: MITPress. 
Hall, R. E. and C. I. Jones (1999): Why do some countries produce so much more output per worker than others? Quarterly Journal of Economics, 114, 83-116.

Higgins, M. (1998): Demography, national savings, and international capital flows. International Economic Review, 39, 343-369.

Holmstrom, B. and J. Tirole (1993): Market liquidity and performance monitoring. Journal of Political Economy, 101, 678-709.

Jappelli, T., and F. Modigliani (1998), The Age-Saving Profile and the Life-Cycle Hypothesis, CSEF Working Paper No. 4, University of Salerno.

Januszewski, S., J. Köke and J. Winter (1999): Product market competition, corporate governance and firm performance: an empirical analysis for Germany. Discussion Paper No. 99-63, Zentrum für Europäische Wirtschaftsforschung, Mannheim.

Jensen, M. C. and W. R. Meckling (1976): Theory of the firm: Managerial behavior, agency costs, and ownership structure. Journal of Financial Economics, 3, 305-360.

Jensen, M. C. and K. J. Murphy (1990): Performance pay and top-management incentives. Journal of Political Economy, 98, 225-264.

Kim, J.-I., and L.J. Lau (1994): The Sources of Economic Growth of the East Asian Newly Industrialized Countries, Journal of the Japanese and International Economies, 8, 235-271.

Levine, R. (1997): Financial development and economic growth: Views and agenda. Journal of Economic Literature, 35, 688-726.

Levine, R., N. Loayza and T. Beck (2000): Financial intermediation and growth: Causality and causes. Journal of Monetary Economics, 46, 31-77.

Levine, R. and S. Zervos (1998): Stock Markets, Banks, and Economic Growth, American Economic Review, 88:3, 537-58.

Loayza, N., K. Schmidt-Hebbel and L. Serven (2000): What drives saving across the world? Review of Economics and Statistics, 82, 165-181.

McKinsey Global Institute (1996): Capital Productivity. Washington, D.C.: McKinsey Global Institute.

Miles, D. and A. Timmermann (1999): Risk sharing and transition costs in the reform of pension systems in Europe. Economic Policy, 29, 253-286.

Mueller, D.C. and B.B. Yurtoglu (2000): Country Legal Environments and Corporate Investment Performance. German Economic Review, 1:2, 187-220.

Nesbitt, S. L. (1994): Long-term rewards from shareholder activism: A study of the CalPERS effect. Journal of Applied Corporate Governance, 6, 75-80.

Neusser, K. and M. Kugler (1998): Manufacturing growth and financial development: Evidence from OECD countries. Review of Economics and Statistics, 80, 638-646.

Organization of Economic Cooperation and Development (1988): Ageing Populations: The Social Policy Implications, Paris: OECD. 
Porter, M. E. (1992): Capital Disadvantage: America's Failing Capital Investment System. Harvard Business Review, 70:5, 65-82.

Poterba, J.M. (1994): International Comparisons of Household Savings. Chicago: The University of Chicago Press.

Pound, J. (1988): Proxy contests and the efficiency of shareholder oversight. Journal of Financial Economics, 20, 237-265.

Rajan, R.G., and L. Zingales (1998): Financial Dependence and Growth, American Economic Review, 88:3, 559-88.

Reisen, H. (2000): Pensions, Savings and Capital Flows: From Aging to Emerging Markets. Edward Elgar.

Rosevaere, D., W. Leibfritz, D. Fore and E. Wurzel (1996): Ageing Populations, Pension Systems and Government Budgets: Simulation for 20 OECD Countries, Paris: OECD.

Samwick, A. A. (2000): Is pension reform conducive to higher saving? Review of Economics and Statistics, 82, 264-272.

Schnabel, R. (1999a): The declining participation in the German PAYG pension system. Discussion Paper No. 99-42, Sonderforschungsbereich 504, Universität Mannheim.

Schnabel, R. (1999b): The golden years of social security - life-cycle income, pensions and savings in Germany. Discussion Paper No. 99-40, SFB 504, Universität Mannheim.

Sinn, H.W. (2000), Why To Fund and Why not to Fund, International Tax and Public Finance.

Smith, M. P. (1996): Shareholder activism by institutional investors: Evidence from CalPERS. Journal of Finance, 51, 227-252.

Wenger, E. and C. Kaserer (1998): The German System of Corporate Governance - A Model which should not be imitated. In: S. Black and M. Moersch (eds.): Competition and Convergence in Financial Markets: The German and Anglo-American Models. Amsterdam: Elsevier. 41-78.

World Bank (1994): Averting the Old Age Crisis. Oxford: Oxford University Press.

Wurgler, J. (2000): Financial markets and the allocation of capital. Journal of Financial Economics, 58, 187-214.

Young, A. (1994): Lessons from the East Asian NICs: A Contrarian View, European Economic Review, 38. 
Table 1-1: The future of pay-as-you-go pension systems

$1995 \quad 2010 \quad 2030$

\begin{tabular}{lccc}
\hline France & & & \\
Pension expenditures (\%GDP) & 12.5 & 12.6 & 19.4 \\
Equilibrium contribution rate (\%wage bill) & 24.3 & 24.4 & 37.7 \\
Fiscal deficit (\%wage bill) & 0.5 & 0.6 & 100.5 \\
Germany & & & \\
Pension expenditures (\%GDP) & 10.0 & 11.0 & 18.4 \\
Equilibrium contribution rate (\%wage bill) & 22.6 & 24.7 & 41.1 \\
Fiscal deficit (\%wage bill) & $(1.1)^{\mathrm{a}}$ & 8.8 & 115.6 \\
Italy & & & \\
Pension expenditures (\%GDP) & 16.0 & 15.2 & 23.3 \\
Equilibrium contribution rate (\%wage bill) & 42.6 & 40.4 & 61.9 \\
Fiscal deficit (\%wage bill) & 0 & 29.9 & 186.8 \\
\hline
\end{tabular}

Notes: The equilibrium contribution rate is the percent of the wage bill required if the increase in pension expenditures is financed by contributions only. The fiscal deficit is the percent of the wage bill arising if the increase in pension expenditures is financed by debt only. a) Surplus.

Source: Chand and Jaeger (1996). 
Table 1-2: Capital market features, 1996

\begin{tabular}{|c|c|c|c|c|c|c|}
\hline & \multicolumn{3}{|c|}{ Pay-as-you-go systems } & \multicolumn{3}{|c|}{ Partially funded systems } \\
\hline & France & Germany & Italy & Netherlands & UK & US \\
\hline $\begin{array}{l}\text { Share of stocks held by households } \\
\text { and institutional investors }(\%)^{a}\end{array}$ & 6.5 & 11.4 & 8.3 & . & 59.8 & 43.4 \\
\hline $\begin{array}{l}\text { Share of pension funds } \\
(\% \text { of household assets })^{b}\end{array}$ & 3 & 2 & 2 & . & 25 & 20 \\
\hline $\begin{array}{l}\text { Stock market capitalization } \\
(\% \text { of GDP })^{c}\end{array}$ & 26.3 & 22.9 & 21.4 & 96.5 & 87.0 & 55.1 \\
\hline $\begin{array}{l}\text { Size of pension funds } \\
(\% \text { of GDP })^{b}\end{array}$ & 5.6 & 3 & 4 & 92 & 77 & 62 \\
\hline $\begin{array}{l}\text { Size of pension funds } \\
\text { (billion USD) }^{b}\end{array}$ & . & 65 & 43 & 363 & 897 & 4,752 \\
\hline
\end{tabular}

Sources: a) OECD Financial Accounts; b) Bank for International Settlements (1998), Table V.5. c) World Bank, 1998, Table 5.2; 
Table 1-3: Capital performance relative to the United States

\begin{tabular}{lccc}
\hline & France & Germany & Italy \\
\hline Aggregate return on investment $^{\mathrm{a}}$ & 71 & 70 & 58 \\
Mean return on investment (firm sample) $^{\mathrm{b}}$ & 64 & 59 & 40 \\
Median return on investment (firm sample) $_{\mathrm{b}}$ & 78 & 82 & 51 \\
Market sector capital productivity $^{\mathrm{c}}$ & 72 & 67 &. \\
Total factor productivity $^{\mathrm{d}}$ & 82 & 81 & 84 \\
\hline
\end{tabular}

Note: All figures are expressed as percentage of the corresponding U.S. value.

Sources: a) Mueller and Yurtoglu (1998), Table 2. b) ditto, Table 5. c) Börsch-Supan (1998b), Table 3. d) Computed from Hall and Jones (1996), Table 9. 
Table 1-4: Composition of household wealth, Germany, 1978--1993

\begin{tabular}{|lccccc|}
\hline & $\mathbf{1 9 7 8}$ & $\mathbf{1 9 8 3}$ & $\mathbf{1 9 8 8}$ & $\mathbf{1 9 9 3}$ & \\
\hline Savings accounts & 15.534 & 12.224 & 13.287 & 11.120 & $17.5 \%$ \\
Building societies & 6.225 & 5.957 & 4.998 & 4.744 & $7.5 \%$ \\
Stocks and bonds & 7.430 & 8.957 & 10.381 & 19.948 & $31.4 \%$ \\
Life insurance (cash value) & 16.719 & 16.821 & 22.379 & 21.141 & $33.3 \%$ \\
Other financial wealth & - & 1.811 & 1.784 & 6.614 & $10.4 \%$ \\
\hline Gross financial wealth & 45.909 & 45.770 & 52.830 & 63.567 & $100.0 \%$ \\
\hline /. consumer loans & 23.043 & 28,859 & 30.266 & 35.055 & \\
\hline Net financial wealth & 22.866 & 16.912 & 22.563 & 28.512 & \\
\hline
\end{tabular}

Note: Household data from the Einkommens- and Verbrauchsstichprobe (EVS). All figures in DM and in 1993 prices.

Source: Börsch-Supan et al. (1999). 
Table 4-1: Granger-causality tests for GDP growth and stock market capitalization, 1988-97

\begin{tabular}{lllll}
\hline Right-hand side variable & Coefficient & $t$-statistic & Observations & Total $R^{2}$ \\
\hline (SMC / GDP) as of period $t-1$ & .0177 & 4.19 & 189 & 0.068 \\
(SMC / GDP) as of period $t$ & .0155 & 3.95 & 211 & 0.064 \\
(SMC / GDP) as of period $t+1$ & .0095 & 1.38 & 190 & 0.019 \\
\hline
\end{tabular}

Notes: Dependent variable is the annual rate of GDP growth as of period $t$. All regressions contain country fixed effects. 
Figure 1-1: The triangle of population aging, savings behavior and capital markets

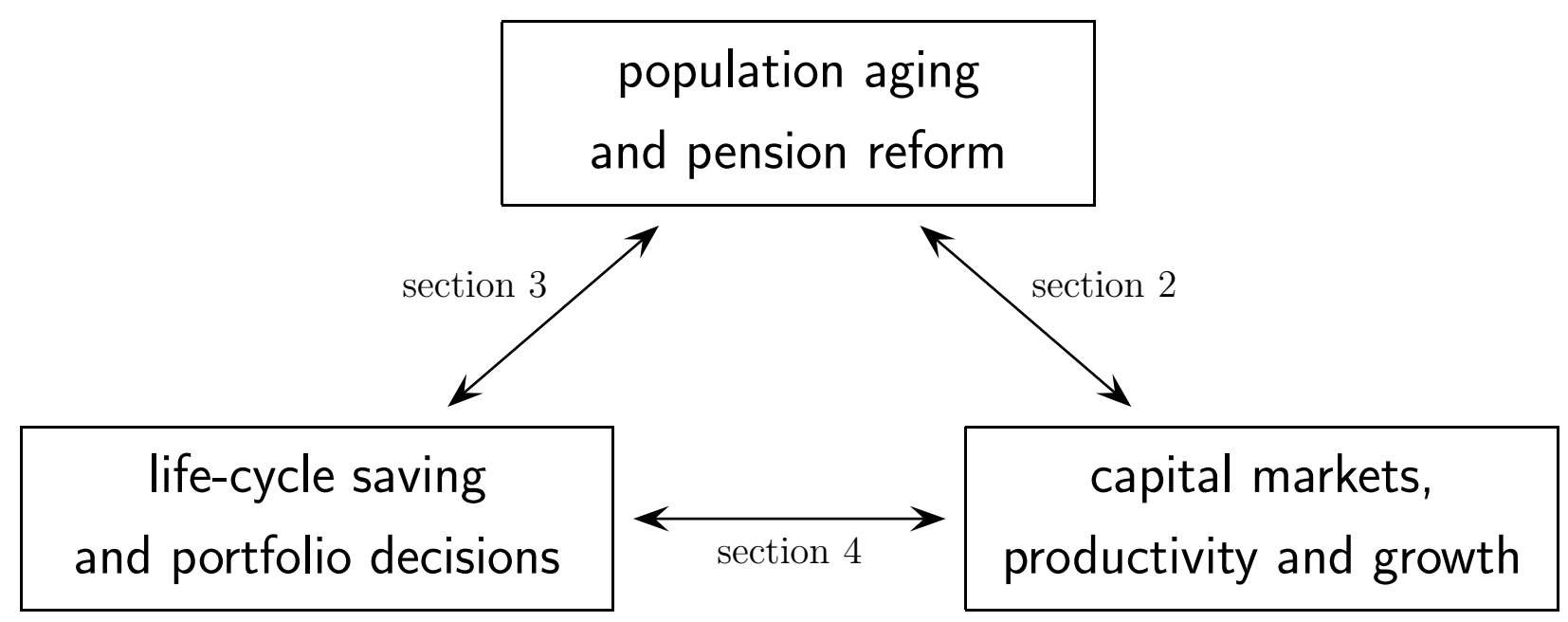









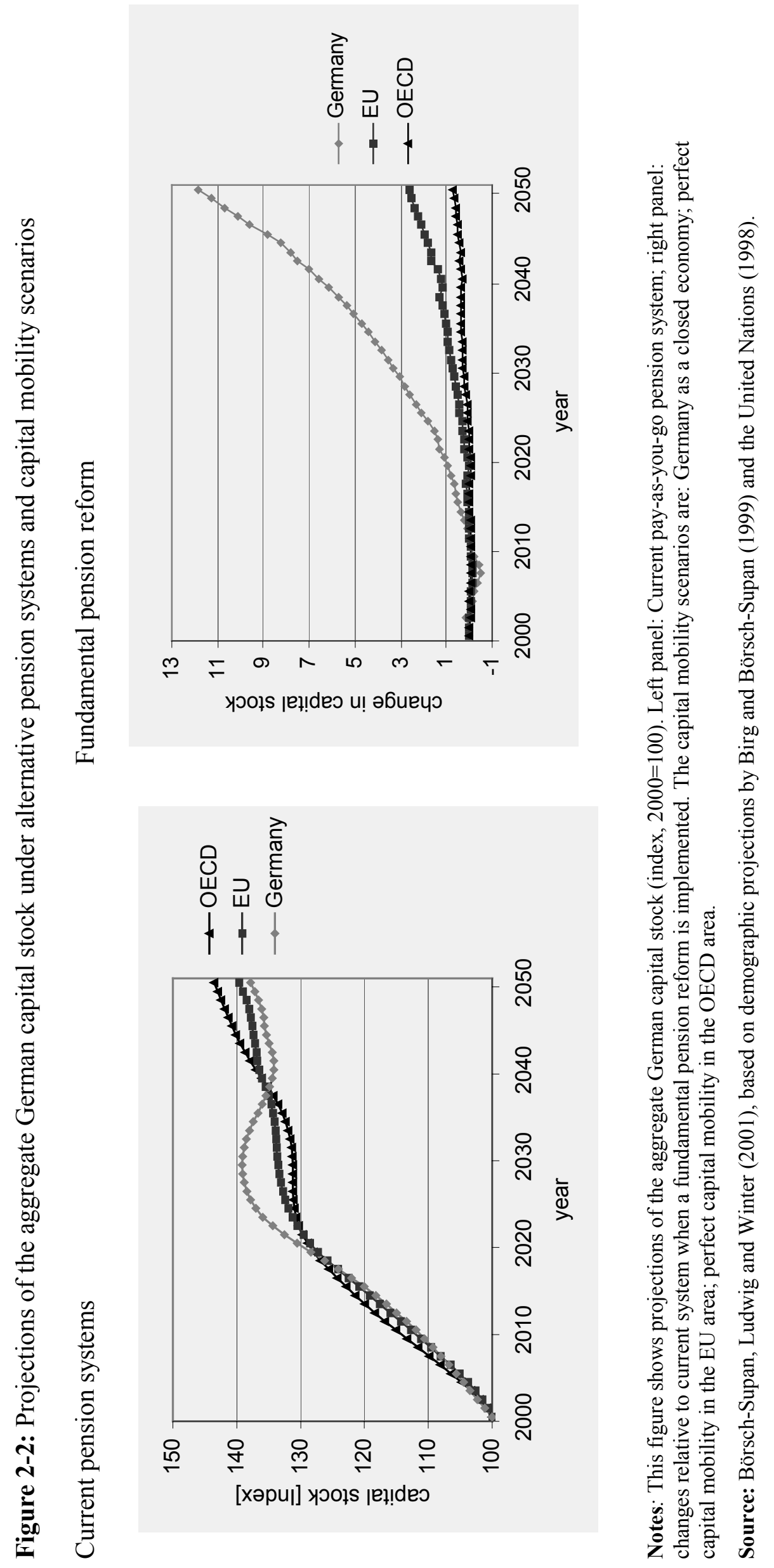




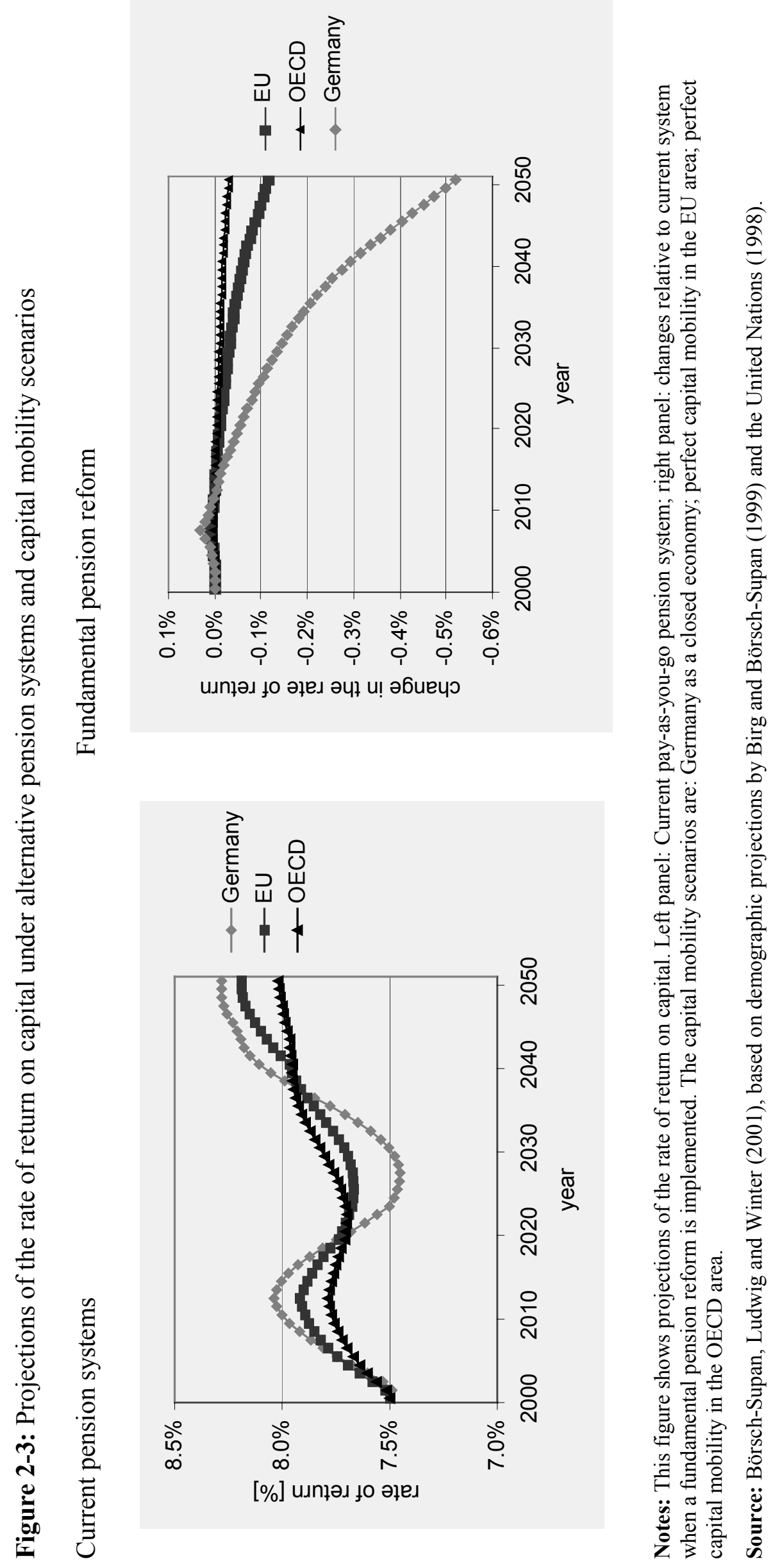


Figure 3-1: Cohort-corrected savings rates by age, Germany

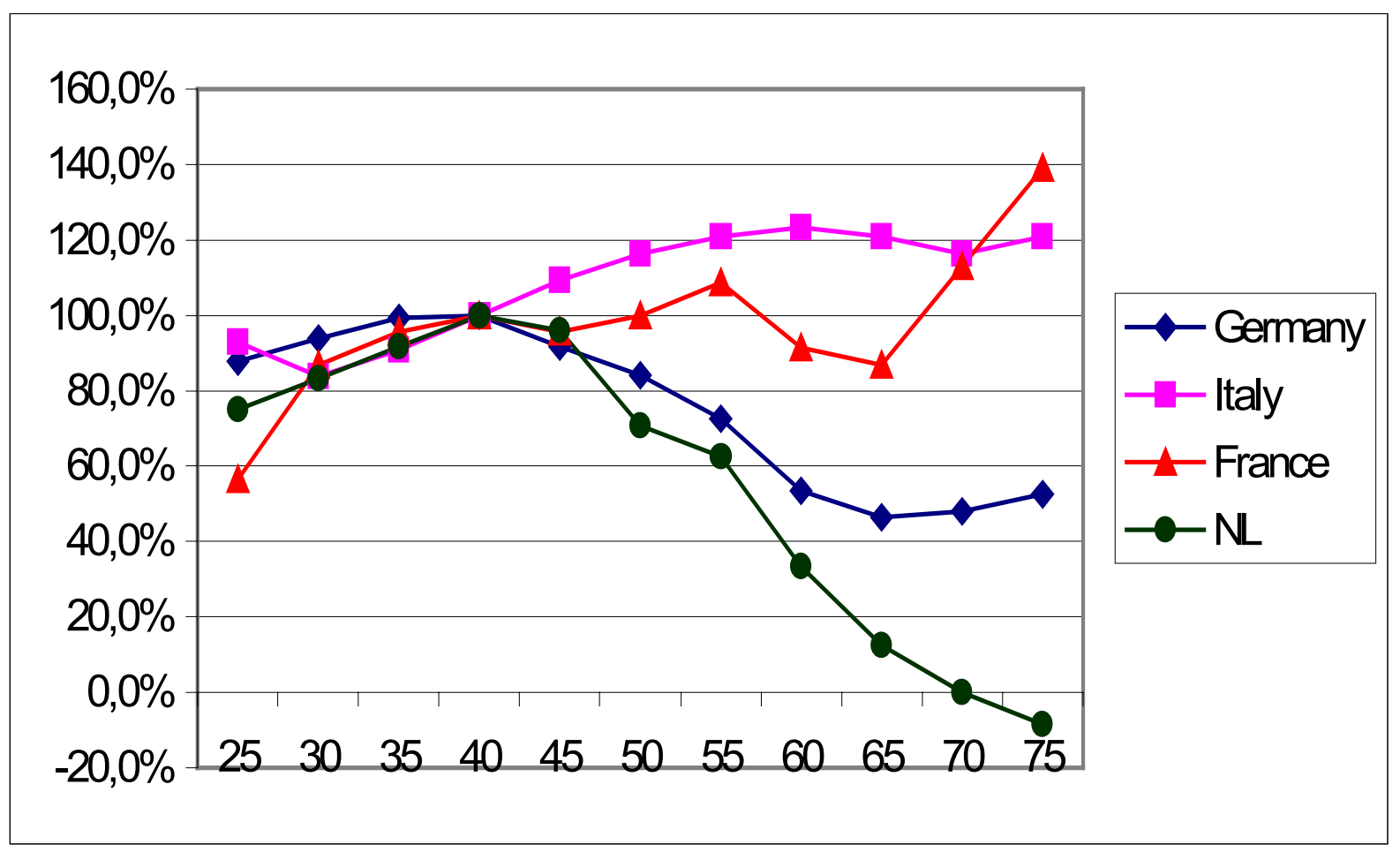

Sources: France: Fall (2001); Germany: Börsch-Supan, Reil-Held, Rodepeter, Schnabel and Winter (2001); Italy: Brugiavini and Padula (2001); Netherlands: Alessie and Kapteyn (2001). 
Figure 4-1: Stock market capitalization and output growth, 10 OECD countries, 1990-98

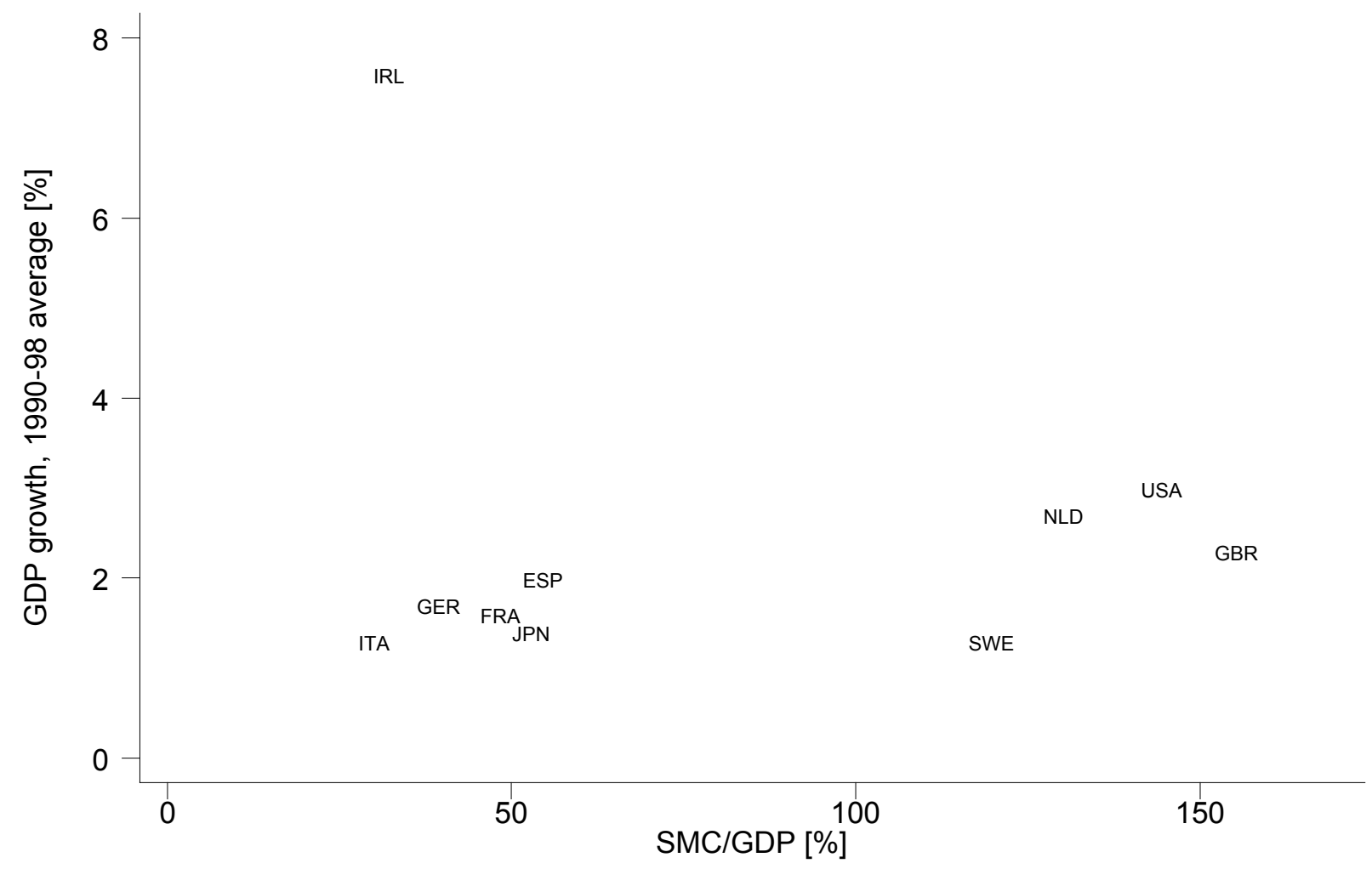

Notes: The horizontal axis displays stock market capitalization as a percentage of GDP in 1997. The vertical axis displays the average annual growth rate of GDP over the period 1990-1998.

Source: Authors' calculations based on data from the OECD Development Report database. 
Figure 4-2: Pension fund assets and output growth, 9 OECD countries, 1990-98

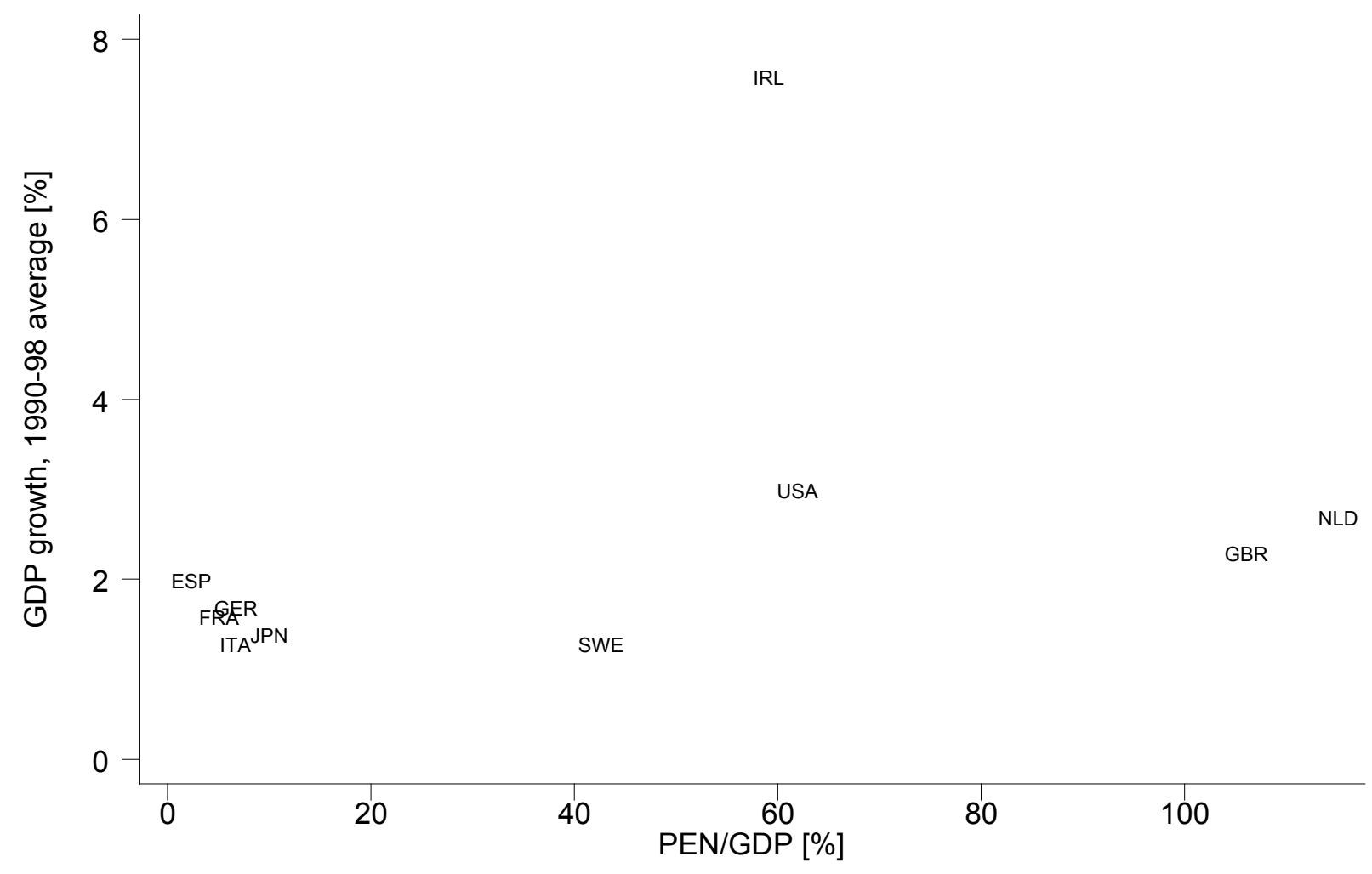

Notes: The horizontal axis displays pension fund investment as a percentage of GDP in 1999 (for USA 1996). The vertical axis displays the average annual growth rate of GDP over the period 1990-1998.

Source: Authors' calculations based on data from the OECD Development Report database (GDP growth), Merrill Lynch (2001) and Bank for International Settlements (1998). 
Figure 4-3: Stock market capitalization and total factor productivity, 8 OECD countries, 1996

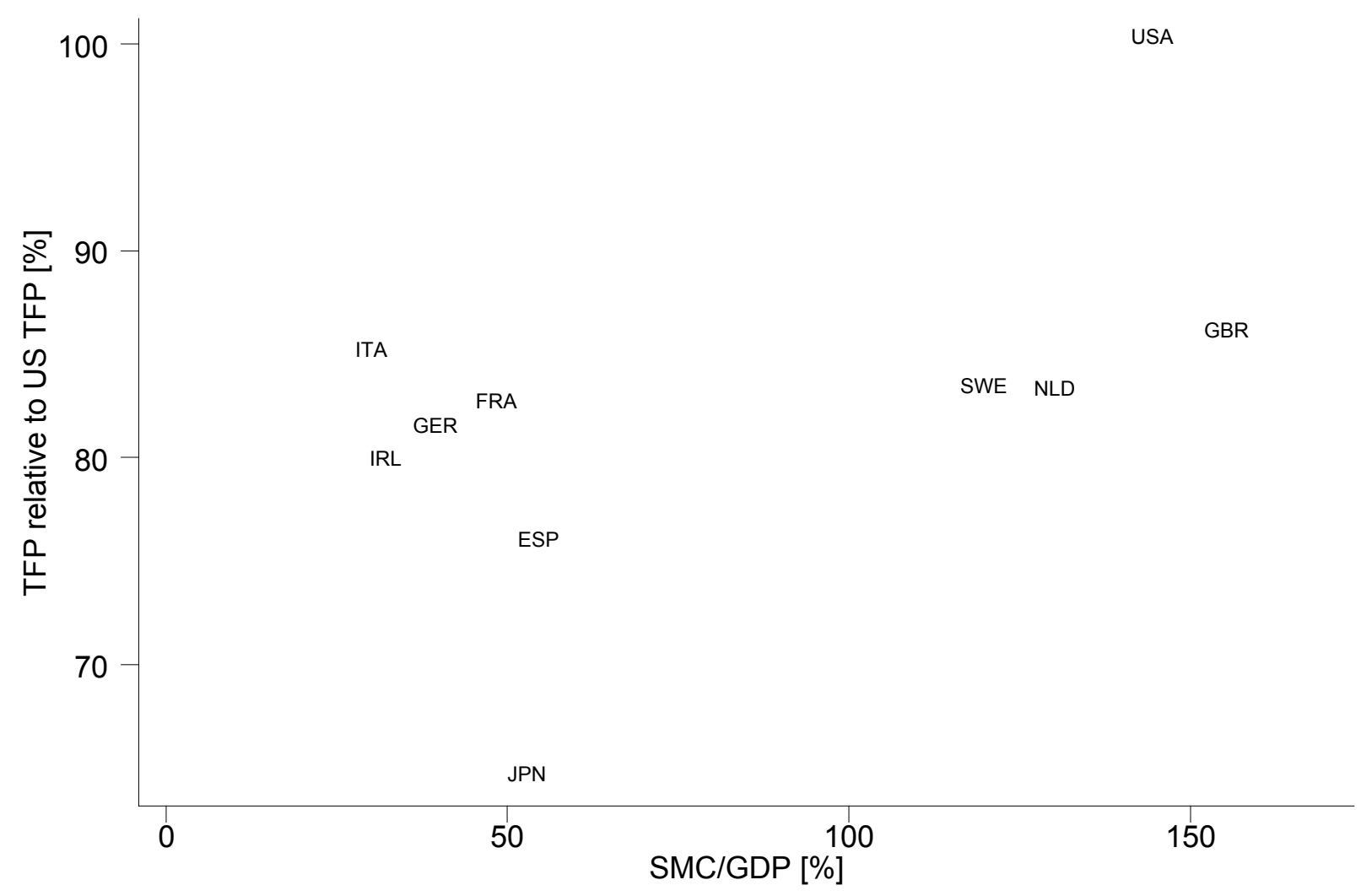

Notes: he horizontal axis displays stock market capitalization as a percentage of GDP. The vertical axis represents total factor productivity as percent of U.S. total factor productivity.

Sources: Authors' calculations based on data from the OECD Development Report database, and from Hall and Jones (1996). 
Figure 4-4: Aggregate rate of return during different 20 -year windows

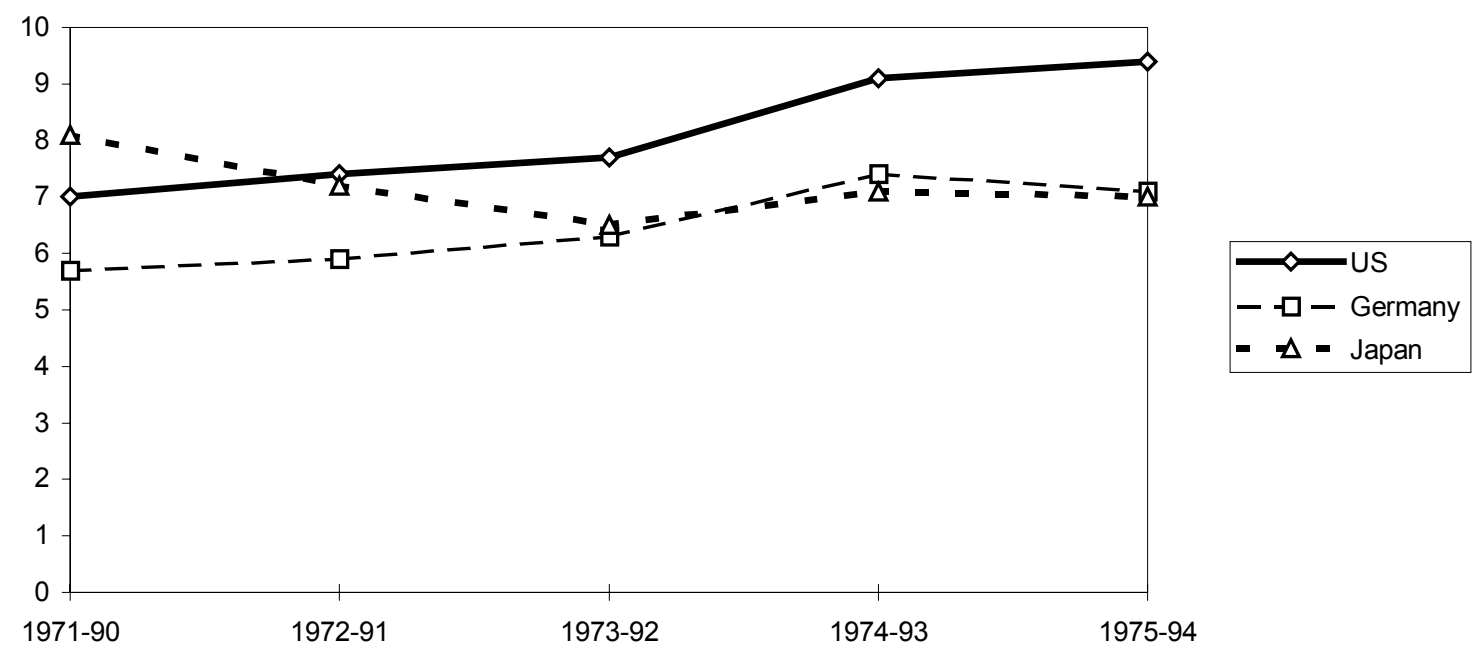

Source: Börsch-Supan (1998b). 
Figure 5-1: Projected welfare effects of improved productivity growth rates on Germany

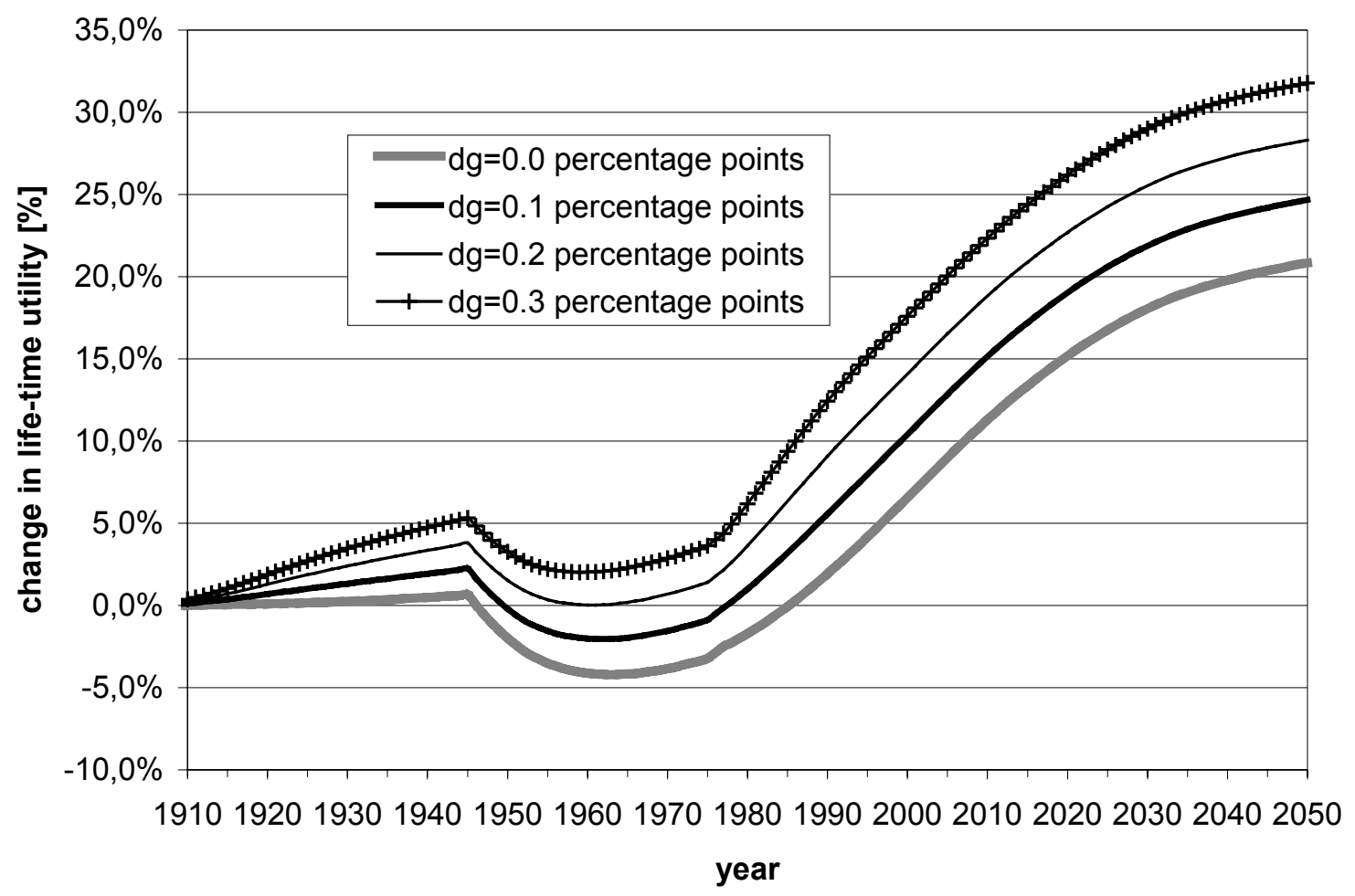

Notes: This figure shows, by birth cohort, the changes in total discounted life-time utility induced by a fundamental pension reform for hypothetical transient improvements in the growth rate of total factor productivity.

Sources: Authors' calculations based on the dynamic general equilibrium model of pension reform by Börsch-Supan et al. (2000). 